\title{
Mesoporous Bioactive Glasses Cytocompatibility Assessment: A Review of In Vitro Studies
}

\author{
Margaux Salètes ${ }^{1,2,+}$, Marta Vartin ${ }^{1,2,+} \mathbb{D}$, Caroline Mocquot ${ }^{2,3}$, Charlène Chevalier ${ }^{2}$, Brigitte Grosgogeat ${ }^{2,4,5} \mathbb{D}$, \\ Pierre Colon ${ }^{2,3}$ and Nina Attik 2,4,*(D)
}

1 CPE Lyon, Université Claude Bernard Lyon 1, CEDEX 08, 69372 Lyon, France; margaux.saletes@cpe.fr (M.S.); marta.vartin@cpe.fr (M.V.)

2 Laboratoire des Multimatériaux et Interfaces, UMR CNRS 5615, Université de Lyon-Université Claude Bernard Lyon 1, CEDEX 08, 69372 Lyon, France; caroline.mocquot@etu.univ-lyon1.fr (C.M.); charlene.chevalier@univ-lyon1.fr (C.C.); brigitte.grosgogeat@univ-lyon1.fr (B.G.); pierre.colon@univ-paris-diderot.fr (P.C.)

3 Assistance Publique-Hôpitaux de Paris, Hôpital Rothschild, Service D'odontologie, Faculté Dentaire, Université de Paris, 75012 Paris, France

4 Faculté d'Odontologie, Université de Lyon, Université Claude Bernard Lyon 1, 69008 Lyon, France

5 Hospices Civils de Lyon, Service D'odontologie, 69007 Lyon, France

* Correspondence: nina.attik@univ-lyon1.fr; Fax: +33-4-78-77-87-12

+ These authors contributed equally to this work.

Citation: Salètes, M.; Vartin, M.; Mocquot, C.; Chevalier, C.; Grosgogeat, B.; Colon, P.; Attik, N. Mesoporous Bioactive Glasses Cytocompatibility Assessment: A Review of In Vitro Studies. Biomimetics 2021, 6, 9. https://doi.org/10.3390/ biomimetics6010009

Received: 14 December 2020

Accepted: 20 January 2021

Published: 23 January 2021

Publisher's Note: MDPI stays neutral with regard to jurisdictional claims in published maps and institutional affiliations.

Copyright: (c) 2021 by the authors. Licensee MDPI, Basel, Switzerland. This article is an open access article distributed under the terms and conditions of the Creative Commons Attribution (CC BY) license (https:// creativecommons.org/licenses/by/ $4.0 /)$.

\begin{abstract}
Thanks to their high porosity and surface area, mesoporous bioactive glasses (MBGs) have gained significant interest in the field of medical applications, in particular, with regards to enhanced bioactive properties which facilitate bone regeneration. The aim of this article is to review the state of the art regarding the biocompatibility evaluation of MBGs and provide a discussion of the various approaches taken. The research was performed using PubMed database and covered articles published in the last five years. From a total of 91 articles, 63 were selected after analyzing them according to our inclusion and exclusion criteria. In vitro methodologies and techniques used for biocompatibility assessment were investigated. Among the biocompatibility assessment techniques, scanning electron microscopy (SEM) has been widely used to study cell morphology and adhesion. Viability and proliferation were assessed using different assays including cell counting and/or cell metabolic activity measurement. Finally, cell differentiation tests relied on the alkaline phosphatase assay; however, these were often complemented by specific bimolecular tests according to the exact application of the mesoporous bioactive glass. The standardization and validation of all tests performed for MBG cytocompatibility is a key aspect and crucial point and should be considered in order to avoid inconsistencies, bias between studies, and unnecessary consumption of time. Therefore, introducing standard tests would serve an important role in the future assessment and development of MBG materials.
\end{abstract}

Keywords: mesoporous bioactive glasses; in vitro; cytocompatibility; bioactivity; medical applications

\section{Introduction}

Bioactive glasses (BGs) represent a major discovery in tissue repair. The first BG ever synthesized was the 4555 Bioglass ${ }^{\circledR}$ in 1969 by Professor Larry Hench and was a clinical success for cochlear bone repair [1]. It marked the beginning of the development from bio-inert materials towards bioactive materials that have the property of interacting closely with tissues to drive regeneration [2].

BG's bioactivity is attributed to the two following properties [3]:

- $\quad$ The formation of a biomimetic hydroxyapatite layer after glass immersion after interaction with biological fluids; 
- The osteogenic ability of some dissolution products and leachable compounds and ions.

From then, the BG technology was well developed, allowing researchers to elaborate new materials, such as BG composites, nanobioactive glasses, doped-BGs, mesoporous bioactive glasses (MBGs) [3].

Nowadays, due to their ease of synthesis and remarkable properties, BGs have found uses in a wide range of medical applications, for example, bone regeneration [4], prosthesis and implant coating [5,6], and hemostasis [7]. In dentistry, BG-based products are also valuable for many clinical indications, such as dental hypersensitivity treatment [8]. A classification of methodologies for BG bioactivity quantification has been recently established, aimed to a better understanding of the bioactive properties of BG regarding dental hard tissues [9].

The current review focuses on MBG-based materials which were first introduced in 2004 [10]. After the melt quench technique, the sol-gel method is the most opted way to prepare such glasses. Use of a bottom-up, low temperature synthesis route with versatile process parameters offers the control needed to achieve particles with enhanced features. Briefly, this process consists of creating a gel by polycondensation of silicon alkoxides $\mathrm{Si}(\mathrm{OR})_{4}$ in an aqueous phase. When a surfactant is introduced to the process, it tends to form three dimensional micellular structures within the gel. The gel is then calcined up to $700{ }^{\circ} \mathrm{C}$ to eliminate the organic components, leaving only the glass and its "cavities" (Figure 1) [11].

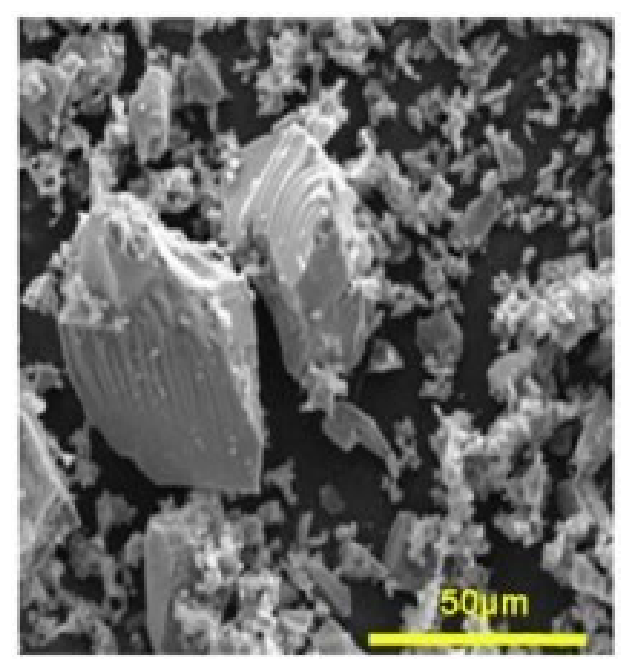

Figure 1. Surface of a mesoporous bioactive glass [11]. Scale bar: $50 \mu \mathrm{m}$.

This specific method gives the mesoporous glass an intrinsic porosity and a very high specific surface area of hundreds of $\mathrm{m}^{2} / \mathrm{g}$, unlike the conventional fusion method that leads to surface areas of few $\mathrm{m}^{2} / \mathrm{g}$. High porosity and specific surface area positively influence the bioactivity through accelerated dissolution of ions from the glass [12-14]. The mesoporous aspect of these glasses was first used for catalytic applications [15]. However, it soon became an essential engineering technique for materials as it was possible to control the porosity by modifying the process parameters. In fact, the size of the pores can even reach the micrometer scale using opal prints instead of surfactants [16] which offers new perspectives for the delivery of high molecular weight molecules [17]. The porosity of MBG has been demonstrated as leading to particular efficiency in promoting remineralization for bone regeneration $[18,19]$. Furthermore, MBG can be doped with different elements to attain new functionalities, such as, $\mathrm{Cu}$-doped MBG which has been reported to have angiogenic and antibiotic effects [20].

MBG-based materials seem to be very promising for medical applications, including in dentistry, and, thus, a significant amount of research has recently been conducted with regards to their effect on the remineralization of calcified dental tissues and the dentin-pulp 
complex tissues. More recently, Mocquot et al. revealed an enhancement of the metabolic activity and the mineralization ability of primary dental pulp cells when they were subjected to MBG-based particles [21].

As MBGs represent a new generation of conventional bioactive glasses with unique properties (high surface area and high porosity) and have the potential for use across a large spectrum of medical applications, important questions should be addressed concerning the evaluation of their biocompatibility. Since the prime focus of researchers is the development of improved bioactive glasses that are mainly safe and suitable for industrial and clinical use, the aim of this review was therefore to identify and rank the different methods used for the MBG biocompatibility assessment in vitro.

\section{Methods}

\subsection{Research Question}

Before any literature investigation, the following research question had been formulated: "How to assess the in vitro biocompatibility of MBG?"

\subsection{Search Strategy}

PubMed was the only electronic database used for this review. The scientific articles published from July 2015 to November 2020 were automatically investigated.

\subsection{Keywords Selection}

Two different keyword combinations were tested and the one resulting with the maximum number of articles was selected.

\subsection{Inclusion and Exclusion Criteria}

To determine the relevant studies needed to conduct the current research review, inclusion and exclusion criteria were established.

The articles were included according to the following rules:

(1) Research article;

(2) Use of mesoporous bioactive glasses with and without scaffolds or composite;

(3) Detailed investigation of biocompatibility in vitro.

On the other hand, the following were systematically removed from our study:

(1) Review articles;

(2) Articles that used non-mesoporous bioactive glasses;

(3) Articles that did not explain their biocompatibility methods;

(4) Articles that did not carry out biocompatibility tests in vitro.

\subsection{Paper Selection and Data Extraction}

Each article abstract was carefully read by the two first authors MS and MV to determine whether or not the article should be included in the study. Once the articles to be included were shortlisted, their full text was then read and investigated to explore different parameters:

- $\quad$ Medical application of the MBG;

- MBG composition and synthesis pathway;

- Cells used for biocompatibility tests;

- $\quad$ Biocompatibility tests performed and their results.

\section{Results}

In view of the small number of articles referring to the dental field, it was decided that the scope should be extended to also assess the biocompatibility of MBGs used for different medical applications. The search equation retained was as follows: "((mesoporous) AND (bioactive) AND (glass)) OR (MBG) AND (biocompatibility)" as it returned the maximum number of articles (Table 1). 
Table 1. Research equations explored.

\begin{tabular}{cc}
\hline Keyword Selection & Number of Articles in PubMed \\
\hline $\begin{array}{c}((\text { mesoporous) AND (bioactive) } \\
\text { AND (glass)) OR (MBG) AND (biocompatibility) }\end{array}$ & 91 \\
\hline $\begin{array}{c}((\text { mesoporous) AND (bioactive) AND (glass)) OR (MBG) } \\
\text { AND (biocompatibility) AND ((dental) OR (tooth) OR (teeth)) }\end{array}$ & 8 \\
\hline
\end{tabular}

Duplicate articles were excluded (one article). Then, the title and abstract of each of the remaining 90 articles were examined allowing the exclusion of 28 articles that did not meet the inclusion criteria (Figure 2). The exclusion reason for each article is described in Table 2. Finally, 63 relevant articles were investigated by reading the full text (Table 3 ).

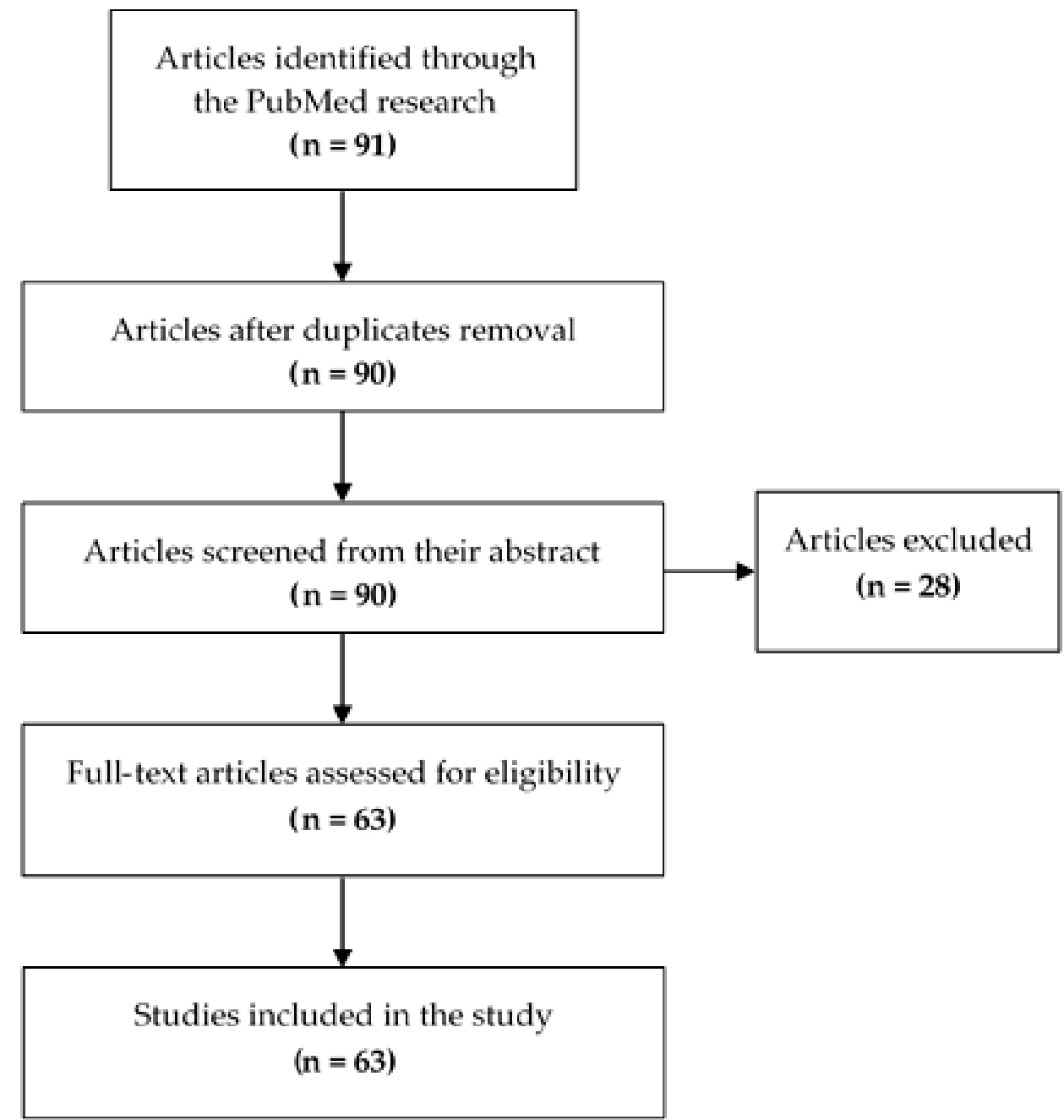

Figure 2. Flow diagram of study identification. 
Table 2. Articles excluded and their grounds for exclusion.

\begin{tabular}{cc}
\hline Articles & Grounds for Exclusion \\
\hline Mao-2016 [22] & \\
Anand-2019 [23] & Only in vivo biocompatibility tests \\
Ghamor-Amegavi-2020 [24] & \\
Lalzawmliana-2019 [25] & \\
\hline Li-2015 [26] & \\
Garg-2017 [27] & \\
Jiang-2017 [28] & \\
Shoaib-2017 [29] & \\
Baino-2018 [30] & \\
Baino-2018 [31] & \\
Fernando-2018 [32] & \\
Kargozar-2018 [33] & \\
Nawaz-2018 [34] & \\
Liu-2018 [35] & \\
Pourshahrestani-2019 [7] & \\
Mubina-2019 [36] & \\
Shadjou-2015 [37] & \\
Baino-2016 [38] & \\
Galarraga-Vinueza-2017 [39] & \\
Vichery-2016 [40] & \\
Fiume-2018 [41] & \\
Kargozar-2018 [42] & \\
Kaya-2018 [43] & \\
Wu-2018 [44] & \\
Lalzawmliana-2020 [45] & \\
Gisbert-Garzarán-2020 [46] & \\
Sistanipour-2018 [47] & \\
Wu-2019 [48] & \\
\hline & \\
\hline
\end{tabular}


Table 3. Articles included and details of each investigation.

\begin{tabular}{|c|c|c|c|c|c|c|c|c|}
\hline References & Aims & MBG Composition & $\begin{array}{l}\text { MBG Compared with } \\
\text { Conventional BG? }\end{array}$ & $\begin{array}{l}\text { MBG Elabos } \\
\text { Method }\end{array}$ & Type of Cells Used & $\begin{array}{l}\text { Culture Setting } \\
\text { (Direct or Indi- } \\
\text { rect Contact) }\end{array}$ & $\begin{array}{l}\text { Techniques Used to Assess } \\
\text { Biocompatibility }\end{array}$ & Main Results \\
\hline $\begin{array}{l}\operatorname{Lin}- \\
2015[49]\end{array}$ & $\begin{array}{l}\text { Bone } \\
\text { regeneration }\end{array}$ & $\begin{array}{l}\text { MBG (no information on the } \\
\text { composition of the MBG) }+ \\
\text { polyglycerol sebacate } \\
\text { (adjuvant) }\end{array}$ & $\begin{array}{l}\text { No } \\
\text { Blank control }\end{array}$ & Sol-gel & $\begin{array}{l}\text { rBMSCs: rat bone marrow } \\
\text { mesenchymal stem cells }\end{array}$ & Direct & $\begin{array}{l}\text { Cell adhesion: Optical density } \\
\text { Cell morphology: CLSM } \\
\text { Cell viability: MTT assay } \\
\text { Cell differentiation: ALP activity } \\
\text { assay and qRT-PCR analysis } \\
(\text { RUNX-2, OCN, OPN) }\end{array}$ & $\begin{array}{l}\text { Same viability and morphology. } \\
\text { Adhesion and proliferation } \\
\text { increased with PGS concentration. } \\
\text { At high concentrations, } \\
\text { biocompatibility decreased } \\
\text { due to acidification. }\end{array}$ \\
\hline $\begin{array}{l}\operatorname{Min}- \\
2015[50]\end{array}$ & $\begin{array}{l}\text { Bone } \\
\text { regeneration }\end{array}$ & $\begin{array}{l}\text { MPHS: MBG 80S15C } \\
\left.\text { (80SiO } \mathrm{S}_{2}: 15 \mathrm{CaO}: 5 \mathrm{P}_{2} \mathrm{O}_{5}\right)+ \\
\text { PHBHHx (adjuvant) }\end{array}$ & $\begin{array}{l}\text { No } \\
\text { Negative control } \\
\text { (without treatment) }\end{array}$ & $3 \mathrm{D}$ printing & $\begin{array}{l}\text { hBMSCs: human bone } \\
\text { marrow mesenchymal } \\
\text { stem cells }\end{array}$ & Direct & $\begin{array}{l}\text { Cell adhesion: SEM } \\
\text { Cell viability: CCK- } 8 \text { assay } \\
\text { Cell differentiation: ALP activity } \\
\text { assay and qRT-PCR analysis } \\
(O C N, O P N, b F G F, S D F-1)\end{array}$ & $\begin{array}{l}\text { Cell morphology: well-extended } \\
\text { MPHS-1.0 and MPHS-1.5 with a } \\
\text { higher DMOG enhanced cell \% rate } \\
\text { Higher ALP activity, expression } \\
\text { levels of OCN and OPN than } \\
\text { MPHS scaffolds. }\end{array}$ \\
\hline $\begin{array}{l}\text { Gómez-Cerezo- } \\
2016 \text { [51] }\end{array}$ & $\begin{array}{l}\text { Bone } \\
\text { regeneration }\end{array}$ & $\begin{array}{l}\mathrm{MBG} 58 \mathrm{~S}\left(58 \mathrm{SiO}_{2}: 37 \mathrm{CaO}:\right. \\
\left.5 \mathrm{P}_{2} \mathrm{O}_{5}\right)+ \text { polycapro-lactone } \\
\text { (adjuvant) }\end{array}$ & $\begin{array}{l}\text { No } \\
\text { Polycaprolactone alone }\end{array}$ & Sol-gel & $\begin{array}{l}\text { MC3T3-E1: murine } \\
\text { osteoblastic cells }\end{array}$ & Direct & $\begin{array}{l}\text { Cell morphology: SEM \& CLSM } \\
\text { Cell viability: Alamar Blue assay } \\
\text { and membrane integrity: LDH: } \\
\text { CytoTox-ONE TM (Promega, G7890) } \\
\text { Cell differentiation: } \\
\text { ALP activity assay }\end{array}$ & $\begin{array}{l}\text { MBG stimulated cell proliferation, } \\
\text { colonization, and differentiation. } \\
\text { Cell migration affected by } \\
\text { architectural features and } \\
\text { enhanced by the chemical release } \\
\text { produced during the } \\
\text { MBG dissolution. }\end{array}$ \\
\hline $\begin{array}{l}\text { Han- } \\
2016[52]\end{array}$ & $\begin{array}{l}\text { Bone } \\
\text { regeneration }\end{array}$ & $\begin{array}{l}\text { MBG (no information on the } \\
\text { composition of the MBG) + } \\
\text { PMMA (adjuvant), } \\
\text { titanium-doped }\end{array}$ & $\begin{array}{l}\text { No } \\
\text { Negative control: no } \\
\text { titanium }\end{array}$ & Sol-gel & $\begin{array}{l}\text { U2OS: human osteosarcoma } \\
\text { cell line }\end{array}$ & Direct & Cell viability: MTT assay & $\begin{array}{l}\text { Slight cytotoxicity for all titanium } \\
\text { concentrations. } \\
\text { No effect on the cell proliferation. }\end{array}$ \\
\hline $\begin{array}{l}\text { Hesaraki- } \\
2016[53]\end{array}$ & $\begin{array}{l}\text { Bone } \\
\text { regeneration }\end{array}$ & $\begin{array}{l}\mathrm{MBG} 64 \mathrm{~S}\left(64 \mathrm{SiO}_{2}: 31 \mathrm{CaO}:\right. \\
\left.5 \mathrm{P}_{2} \mathrm{O}_{5}\right)+ \text { resin } \\
\text { poly-methacrylate } \\
\text { (adjuvant) }\end{array}$ & $\begin{array}{l}\text { No } \\
\text { Resin alone }\end{array}$ & Sol-gel & $\begin{array}{l}\text { Calvarium-derived } \\
\text { newborn rat osteoblasts }\end{array}$ & Direct & $\begin{array}{l}\text { Cell morphology: SEM } \\
\text { Cell viability: MTT assay }\end{array}$ & $\begin{array}{l}\text { Bioactive glass/resin composite } \\
\text { biocompatible and } \\
\text { osteoconductive. }\end{array}$ \\
\hline $\begin{array}{l}\mathrm{Kim}- \\
2016[54]\end{array}$ & $\begin{array}{l}\text { Bone } \\
\text { regeneration }\end{array}$ & $\begin{array}{l}\text { MBG } 85 \mathrm{~S}\left(85 \mathrm{SiO}_{2}: 15 \mathrm{CaO}\right) \\
\text { functionalized with } \\
\text { amino groups }\end{array}$ & $\begin{array}{l}\text { No } \\
\text { Blank control }\end{array}$ & Sol-gel & $\begin{array}{l}\text { RAW264.7: murine } \\
\text { macrophages }\end{array}$ & Direct & $\begin{array}{l}\text { Cell morphology: CLSM } \\
\text { Cell viability: CCK-8 assay } \\
\text { Cell differentiation: qRT-PCR } \\
\text { analysis (c-fos, cathepsin-K, } \\
\text { TRAP, NFATc1) }\end{array}$ & $\begin{array}{l}\text { Cell viability dose and } \\
\text { time dependent. } \\
\text { Morphological characteristics } \\
\text { reflected results of cell viability. }\end{array}$ \\
\hline $\begin{array}{l}\text { Pourshahrestani } \\
\text {-2016 [55] }\end{array}$ & Hemostasis & $\begin{array}{l}\text { Ga-MBGs: MBG } 80 \mathrm{~S}_{15 \mathrm{C}} \\
\left(80 \mathrm{SiO}_{2}: 15 \mathrm{CaO}: 5 \mathrm{P}_{2} \mathrm{O}_{5}\right) \\
\text { doped with gallium } \\
\mathrm{Si} / \mathrm{Ca} / \mathrm{P} / \mathrm{Ga}: 80 / 15 / 5 / 0 ; \\
79 / 15 / 5 / 1 ; 78 / 15 / 5 / 2 ; \\
77 / 15 / 5 / 3\end{array}$ & $\begin{array}{l}\text { No } \\
\text { Control: MBG } \\
\text { without gallium }\end{array}$ & Sol-gel & $\begin{array}{l}\text { HDFs: human dermal } \\
\text { fibroblast cells }\end{array}$ & Indirect & Cell viability: MTT assay & $\begin{array}{l}\text { All glasses were non-cytotoxic. } \\
\text { Cell viability enhanced in the } \\
\text { presence of } 1 \% \text { Ga-MBGs. }\end{array}$ \\
\hline $\begin{array}{l}\text { Singh- } \\
2016[56]\end{array}$ & $\begin{array}{l}\text { Bone } \\
\text { regeneration } \\
\text { and drug } \\
\text { delivery }\end{array}$ & $\begin{array}{l}\text { MBG (no information on the } \\
\text { composition of the MBG) } \\
\text { doped C-dot }\end{array}$ & $\begin{array}{l}\text { No } \\
\text { Blank control }\end{array}$ & Sol-gel & $\begin{array}{l}\text { HeLa cell line, MC3T3-E1 } \\
\text { murine osteoblastic cells, } \\
\text { rBMSCs: rat bone marrow } \\
\text { mesenchymal stem cells }\end{array}$ & Direct & $\begin{array}{l}\text { Cell viability: MTT assay and } \\
\text { CCK-8 assay }\end{array}$ & $\begin{array}{l}\text { High bioactivity in vitro and cell } \\
\text { viability of the developed } \\
\text { nanospheres, equivalent to the } \\
\text { bioactive glass nanoparticles. }\end{array}$ \\
\hline
\end{tabular}


Table 3. Cont

\begin{tabular}{|c|c|c|c|c|c|c|c|c|}
\hline References & Aims & MBG Composition & $\begin{array}{l}\text { MBG Compared with } \\
\text { Conventional BG? }\end{array}$ & $\begin{array}{l}\text { MBG Elabos } \\
\text { Method }\end{array}$ & Type of Cells Used & $\begin{array}{l}\text { Culture Setting } \\
\text { (Direct or Indi- } \\
\text { rect Contact) }\end{array}$ & $\begin{array}{l}\text { Techniques Used to Assess } \\
\text { Biocompatibility }\end{array}$ & Main Results \\
\hline $\begin{array}{l}\text { Tang- } \\
2016[57]\end{array}$ & $\begin{array}{l}\text { Bone } \\
\text { regeneration }\end{array}$ & $\begin{array}{l}\text { TMS/rhBMP-2, TMS } \\
\text { (trimodal MBG scaffold), } \\
\text { MBG with different pore } \\
\text { sizes (macro/micro/ } \\
\text { nano-porous) } \\
\text { (no information on the } \\
\text { composition of the MBG) }\end{array}$ & $\begin{array}{l}\text { No } \\
\text { Blank control }\end{array}$ & Sol-gel & $\begin{array}{l}\text { rBMSCs: rat bone marrow } \\
\text { mesenchymal stem cells and } \\
\text { HUVECs: human umbilical } \\
\text { vein endothelial cells }\end{array}$ & Direct & $\begin{array}{l}\text { Cell morphology: CLSM \& SEM } \\
\text { Cell adhesion: CLSM } \\
\text { Cell viability: LIVE/DEAD assay } \\
\text { Cell differentiation: ALP activity } \\
\text { assay and qRT-PCR analysis } \\
(\text { RUNX-2, OCN, OPN, } \\
\text { BSP, GAPDH) }\end{array}$ & $\begin{array}{l}\text { Excellent cytocompatibility with all } \\
\text { trimodal and bimodal scaffolds } \\
\text { and desirable environment for cells } \\
\text { attachment and colonization. }\end{array}$ \\
\hline $\begin{array}{l}\text { Vishnu Priya- } \\
2016[58]\end{array}$ & $\begin{array}{l}\text { Bone } \\
\text { regeneration }\end{array}$ & $\begin{array}{l}\text { Hydrogel containing } \\
\text { magnesium-doped bioglass } \\
\left(60 \mathrm{SiO}_{2}: 30 \mathrm{CaO}: 10 \mathrm{MgO}\right)\end{array}$ & $\begin{array}{l}\text { No } \\
\text { Control: hydrogel } \\
\text { without MBG }\end{array}$ & Sol-gel & $\begin{array}{l}\text { HUVECs: human umbilical } \\
\text { vein endothelial cells and } \\
\text { ADSCs: rabbit } \\
\text { adipose-derived stem cells }\end{array}$ & Direct & $\begin{array}{l}\text { Cell proliferation: Alamar Blue } \\
\text { Cell adhesion: } \\
\text { Fluorescence microscopy } \\
\text { Cell differentiation: ALP activity, } \\
\text { immunofluorescence (ALP, OCN) }\end{array}$ & $\begin{array}{l}\text { Hydrogels containing MBG } \\
\text { showed early initiation of } \\
\text { differentiation and higher } \\
\text { expression of ALP and osteocalcin } \\
\text { confirming the osteoinductive } \\
\text { property of MBG. }\end{array}$ \\
\hline $\begin{array}{l}\text { Wang-- } \\
2016[20]\end{array}$ & $\begin{array}{l}\text { Bone } \\
\text { regeneration }\end{array}$ & $\begin{array}{l}\mathrm{MBG} 80 \mathrm{~S} 15 \mathrm{C} \\
\left(80 \mathrm{SiO} 2: 15 \mathrm{CaO}: 5 \mathrm{P}_{2} \mathrm{O}_{5}\right) \\
\text { doped with copper } \\
\mathrm{Si} / \mathrm{Ca} / \mathrm{P} / \mathrm{Cu}: \\
78 / 15 / 5 / 2 ; \\
75 / 15 / 5 / 5\end{array}$ & $\begin{array}{l}\text { No } \\
\text { Control: TCPS }\end{array}$ & Sol-gel & $\begin{array}{l}\text { MC3T3: mouse } \\
\text { fibroblast cells }\end{array}$ & $\begin{array}{l}\text { Direct and } \\
\text { indirect }\end{array}$ & $\begin{array}{l}\text { Cell adhesion: SEM } \\
\text { Cell viability: } \\
\text { MTT assay and CLSM } \\
\text { Cell differentiation: qRT-PCR } \\
\text { analysis (VEGF, bFGF and PDGF) }\end{array}$ & $\begin{array}{l}\text { Cytotoxicity of copper dose } \\
\text { dependent. } \\
\text { Copper: proangiogenic } \\
\text { (promotes differentiation) }\end{array}$ \\
\hline $\begin{array}{l}\text { Wu- } \\
2016[59]\end{array}$ & $\begin{array}{l}\text { Bone } \\
\text { regeneration } \\
\text { and } \\
\text { osteoporosis }\end{array}$ & $\begin{array}{l}\text { MBG 80S15C } \\
\left(80 \mathrm{SiO}_{2}: 15 \mathrm{CaO}\right)\end{array}$ & $\begin{array}{l}\text { No } \\
\text { Blank control }\end{array}$ & Sol-gel & $\begin{array}{l}\text { rBMSCs: bone marrow } \\
\text { mesenchymal stem cells } \\
\text { derived from either sham } \\
\text { control or ovariectomized } \\
\text { (OVX) rats }\end{array}$ & Indirect & $\begin{array}{l}\text { Cell proliferation: CCK-8 assay } \\
\text { Cell morphology and cytoskeletal } \\
\text { structure: fluorescence microscopy } \\
\text { Cell differentiation: ALP staining, } \\
\text { Alizarin Red S, Oil Red-O staining, } \\
\text { qRT-PCR (RUNX2, PPAR }, \\
\text { GAPDH), western blot (WB) } \\
\text { (Runx2, PPAR } \gamma, \beta \text {-actin) }\end{array}$ & $\begin{array}{l}\text { Lower concentration of MBG } \\
\text { dissolution can promote } \\
\text { osteogenesis but inhibit } \\
\text { adipogenesis of the sham and } \\
\text { OVX BMSCs. }\end{array}$ \\
\hline $\begin{array}{l}\text { Zhang- } \\
2016[60]\end{array}$ & $\begin{array}{l}\text { Bone } \\
\text { regeneration }\end{array}$ & $\begin{array}{l}\text { Large-pore MBG (no } \\
\text { information on the } \\
\text { composition of the MBG) }\end{array}$ & $\begin{array}{l}\text { No } \\
\text { Blank control }\end{array}$ & Not indicated & $\begin{array}{l}\text { ADSCs: rat adipose-derived } \\
\text { stem cells }\end{array}$ & Direct & $\begin{array}{l}\text { Cell morphology: SEM } \\
\text { Cell viability: MTS assay } \\
\text { Cell differentiation: qRT-PCR } \\
\text { analysis }(A L P, \text { OCN, OPG, } \\
\text { PPAR gamma) }\end{array}$ & $\begin{array}{l}\text { Proliferation related to ions } \\
\text { released. } \\
\text { Large pore mesoporous glass } \\
\text { promotes the expression of } \\
\text { osteogenic-related genes but also } \\
\text { inhibit the expression of } \\
\text { adipogenic genes. }\end{array}$ \\
\hline $\begin{array}{l}\text { Zhang- } \\
2016[61]\end{array}$ & $\begin{array}{l}\text { Bone } \\
\text { regeneration }\end{array}$ & $\begin{array}{l}\text { MBG } 80 \mathrm{~S} 15 \mathrm{C} \\
\left(80 \mathrm{SiO}_{2}: 15 \mathrm{CaO}: 5 \mathrm{P}_{2} \mathrm{O}_{5}\right) \\
\text { functionalized with } \\
\text { amino groups }\end{array}$ & $\begin{array}{l}\text { No } \\
\text { Blank control }\end{array}$ & Sol-gel & $\begin{array}{l}\text { Rabbit BMSCs: bone } \\
\text { marrow mesenchymal } \\
\text { stem cells }\end{array}$ & Direct & $\begin{array}{l}\text { Cell adhesion: SEM } \\
\text { Cell viability: MTT assay } \\
\text { Cell differentiation: ALP activity } \\
\text { assay \& qRT-PCR analysis } \\
(A L P, B S P, O C N, R U N X-2)\end{array}$ & $\begin{array}{l}\text { Amino-MBGS: the most potent } \\
\text { proliferative effect and the most } \\
\text { effective osteoblastic } \\
\text { differentiation potential. }\end{array}$ \\
\hline
\end{tabular}


Table 3. Cont

\begin{tabular}{|c|c|c|c|c|c|c|c|c|}
\hline References & Aims & MBG Composition & $\begin{array}{l}\text { MBG Compared with } \\
\text { Conventional BG? }\end{array}$ & $\begin{array}{l}\text { MBG Elabos } \\
\text { Method }\end{array}$ & Type of Cells Used & $\begin{array}{l}\text { Culture Setting } \\
\text { (Direct or Indi- } \\
\text { rect Contact) }\end{array}$ & $\begin{array}{l}\text { Techniques Used to Assess } \\
\text { Biocompatibility }\end{array}$ & Main Results \\
\hline $\begin{array}{l}\mathrm{Ge}- \\
2017[62]\end{array}$ & $\begin{array}{l}\text { Bone } \\
\text { regeneration }\end{array}$ & $\begin{array}{l}\text { MBG on nanoTitanium film, } \\
\text { doped with growth factor. } \\
\text { Special composition related } \\
\text { to doping: } \\
\mathrm{SiO}_{2} / \mathrm{CaO} / \mathrm{P}_{2} \mathrm{O}_{5} / \mathrm{TiO}_{2}: \\
80 / 5 / 5 / 10\end{array}$ & $\begin{array}{l}\text { No } \\
\text { Control without } \\
\text { the drug }\end{array}$ & Sol-gel & $\begin{array}{l}\text { rBMSCs: rat bone marrow } \\
\text { mesenchymal stem cells }\end{array}$ & Direct & $\begin{array}{l}\text { Cell differentiation: ALP activity } \\
\text { assay and qRT-PCR analysis } \\
(C O L-1, O C N)\end{array}$ & $\begin{array}{l}\text { Highest ALP activity and strong } \\
\text { Col-I and OCN expressions on } \\
200-\mathrm{MBG} \text { film cells: possibly, due } \\
\text { to the surface of the glass that } \\
\text { accelerates the signal transduction. }\end{array}$ \\
\hline $\begin{array}{l}\text { Kaur- } \\
2017[63]\end{array}$ & $\begin{array}{l}\text { Bone } \\
\text { regeneration }\end{array}$ & $\begin{array}{l}\text { MBG } 64 \mathrm{~S}\left(64 \mathrm{SiO}_{2}: 31 \mathrm{CaO}:\right. \\
\left.5 \mathrm{P}_{2} \mathrm{O}_{5}\right) \text { doped with copper } \\
(2.5 \text { to } 10 \%)\end{array}$ & $\begin{array}{l}\text { No } \\
\text { Blank control }\end{array}$ & Sol-gel & $\begin{array}{l}\text { J774A.1: murine } \\
\text { macrophage cell line }\end{array}$ & Direct & $\begin{array}{l}\text { Cell viability: MTT assay and } \\
\text { Membrane integrity: } \\
\text { Trypan Blue assay }\end{array}$ & $\begin{array}{l}\text { High concentrations of copper } \\
\text { (from } 1,95 \mu \mathrm{g} / \mathrm{mL} \text { ): toxic. With the } \\
\text { decrease in concentration, all the } \\
\text { MBGs increased live cell and } \\
\text { decreased dead cell rates. }\end{array}$ \\
\hline $\begin{array}{l}\mathrm{Li}- \\
2017[64]\end{array}$ & Gene delivery & $\begin{array}{l}\text { MBG (no information on the } \\
\text { composition of the MBG) + } \\
\text { polyglycerol + } \mathrm{Arg}_{8} \text { (to } \\
\text { functionalize polymer), } \\
\text { loaded with DNA }\end{array}$ & $\begin{array}{l}\text { No } \\
\text { Blank control }\end{array}$ & Sol-gel & $\begin{array}{l}\text { Human HeLa cervical } \\
\text { cancer cell line }\end{array}$ & Direct & $\begin{array}{l}\text { Cell viability: LIVE/DEAD assay } \\
\text { and CCK- } 8 \text { assay }\end{array}$ & $\begin{array}{l}\text { Good cell biocompatibility. Most } \\
\text { cells in the complex-treated groups } \\
\text { grew well in contact with the } \\
\text { MBG/DOX-treated group. }\end{array}$ \\
\hline $\begin{array}{l}\text { Luo-- } \\
2017[65]\end{array}$ & $\begin{array}{l}\text { Bone } \\
\text { regeneration }\end{array}$ & $\begin{array}{l}\text { Nanofibrous MBG (no } \\
\text { information on the } \\
\text { composition of the MBG) }\end{array}$ & $\begin{array}{l}\text { No } \\
\text { Blank control }\end{array}$ & Sol-gel & Mouse osteoblasts & Direct & $\begin{array}{l}\text { Cell morphology: SEM \& } \\
\text { Fluorescence microscopy } \\
\text { Cell viability: LIVE/DEAD assay } \\
\text { and CCK-8 assay } \\
\text { Cell differentiation: } \\
\text { ALP activity assay }\end{array}$ & $\begin{array}{l}60540 \text { C scaffolds: favorable } \\
\text { support for cell growth, } \\
\text { proliferation, and differentiation. }\end{array}$ \\
\hline $\begin{array}{l}\text { Luo-- } \\
2017[66]\end{array}$ & $\begin{array}{l}\text { Bone } \\
\text { regeneration }\end{array}$ & $\begin{array}{l}\text { NanoMBG } 58 \mathrm{~S}\left(58 \mathrm{SiO}_{2}:\right. \\
\left.37 \mathrm{CaO}: 5 \mathrm{P}_{2} \mathrm{O}_{5}\right)\end{array}$ & $\begin{array}{l}\text { No } \\
\text { Blank control }\end{array}$ & $\begin{array}{l}\text { Aerogel-based } \\
\text { method }\end{array}$ & $\begin{array}{l}\text { Primary mouse } \\
\text { osteoblast cells }\end{array}$ & Direct & $\begin{array}{l}\text { Cell morphology: } \\
\text { Fluorescence microscopy } \\
\text { Cell adhesion: } \\
\text { Fluorescence microscopy } \\
\text { Cell viability: CCK-8 assay } \\
\text { Cell differentiation: } \\
\text { ALP activity assay }\end{array}$ & $\begin{array}{l}58 \mathrm{~S} \text { scaffold: more cells growth and } \\
\text { cell differentiation than scaffold } \\
\text { without } 58 \mathrm{~S} \text {. }\end{array}$ \\
\hline $\begin{array}{l}\text { Pourshahrestani } \\
-2017[67]\end{array}$ & Hemostasis & $\begin{array}{l}\text { MBG 80S15C }\left(80 \mathrm{SiO}_{2}:\right. \\
\left.15 \mathrm{CaO}: 5 \mathrm{P}_{2} \mathrm{O}_{5}\right) \text { doped with } \\
\text { gallium (Ga) + chitosan } \\
\text { (CHT = adjuvant) } \\
\mathrm{Si} / \mathrm{Ca} / \mathrm{P} / \mathrm{Ga} \text { : 79/15/5/1 } \\
\mathrm{Ga}-\mathrm{MBG} / \mathrm{CHT}(\text { wt. } \%): \\
\text { 10/90; 30/70; } 50 / 50\end{array}$ & $\begin{array}{l}\text { No } \\
\text { Negative control: } \\
\text { chitosan alone }\end{array}$ & Sol-gel & $\begin{array}{l}\text { HDFs: human dermal } \\
\text { fibroblast cells }\end{array}$ & Direct & $\begin{array}{l}\text { Cell viability: Alamar Blue assay } \\
\text { and LIVE/DEAD assay } \\
\text { Cell morphology: CLSM }\end{array}$ & $\begin{array}{l}\text { Good biocompatibility. } \\
\text { No cytotoxicity. }\end{array}$ \\
\hline $\begin{array}{l}\text { Qi- } \\
2017[68]\end{array}$ & $\begin{array}{l}\text { Bone } \\
\text { regeneration }\end{array}$ & $\begin{array}{l}\mathrm{MBG} 80 \mathrm{~S}\left(80 \mathrm{SiO}_{2}: 16 \mathrm{CaO}:\right. \\
\left.4 \mathrm{P}_{2} \mathrm{O}_{5}\right)+ \text { calcium sulfate } \\
\text { hydrate (adjuvant) }\end{array}$ & $\begin{array}{l}\text { No } \\
\text { Control: calcium } \\
\text { sulfate hydrate alone }\end{array}$ & 3D printing & $\begin{array}{l}\text { hBMSCs: human bone } \\
\text { marrow mesenchymal } \\
\text { stem cells }\end{array}$ & Direct & $\begin{array}{l}\text { Cell adhesion: SEM } \\
\text { Cell viability: CCK-8 assay } \\
\text { Cell differentiation: ALP activity } \\
\text { assay and qRT-PCR analysis } \\
(A L P, O C N, O P N, R U N X-2)\end{array}$ & $\begin{array}{l}\text { Cell viability, proliferation, and } \\
\text { differentiation increased with } \\
\text { increase MBG concentrations. }\end{array}$ \\
\hline
\end{tabular}


Table 3. Cont.

\begin{tabular}{|c|c|c|c|c|c|c|c|c|}
\hline References & Aims & MBG Composition & $\begin{array}{l}\text { MBG Compared with } \\
\text { Conventional BG? }\end{array}$ & $\begin{array}{l}\text { MBG Elabos } \\
\text { Method }\end{array}$ & Type of Cells Used & $\begin{array}{l}\text { Culture Setting } \\
\text { (Direct or Indi- } \\
\text { rect Contact) }\end{array}$ & $\begin{array}{l}\text { Techniques Used to Assess } \\
\text { Biocompatibility }\end{array}$ & Main Results \\
\hline $\begin{array}{l}\text { Sánchez-Salcedo } \\
\text {-2017 [69] }\end{array}$ & $\begin{array}{l}\text { Bone } \\
\text { regeneration }\end{array}$ & $\begin{array}{l}\text { MBG } 75 \mathrm{~S}\left(75 \mathrm{SiO}_{2}: 20 \mathrm{CaO}:\right. \\
\left.5 \mathrm{P}_{2} \mathrm{O}_{5}\right) \& \mathrm{MBG} 85 \mathrm{~S} \\
\left(85 \mathrm{SiO}_{2}: 15 \mathrm{CaO}\right) \\
\text { both functionalized with } \\
\text { amino groups or lysine }\end{array}$ & $\begin{array}{l}\text { No } \\
\text { Blank control }\end{array}$ & Sol-gel & $\begin{array}{l}\text { MC3T3-E1: mouse } \\
\text { osteoblastic cells }\end{array}$ & Direct & $\begin{array}{l}\text { Cell morphology: } \\
\text { Inverted optical microscopy } \\
\text { Cell adhesion: } \\
\text { Fluorescence microscopy } \\
\text { Cell viability: MTS assay and } \\
\text { membrane integrity: LDH: } \\
\text { CytoTox-ONE TM (Promega, G7890) } \\
\text { Cell differentiation: } \\
\text { ALP activity assay }\end{array}$ & $\begin{array}{l}\text { In vitro cytocompatibility of MBGs } \\
\text { was preserved functionalization. }\end{array}$ \\
\hline $\begin{array}{l}\text { Shoaib- } \\
2017[71]\end{array}$ & $\begin{array}{l}\text { Bone } \\
\text { regeneration }\end{array}$ & $\begin{array}{l}\mathrm{MBG}\left(49 \mathrm{SiO}_{2}: 20 \mathrm{CaO}:\right. \\
20 \mathrm{Na}_{2} \mathrm{O}: 7 \mathrm{~K}_{2} \mathrm{O}: \\
\left.4 \mathrm{P}_{2} \mathrm{O}_{5} \text { mol } \%\right) \text { doped } \\
\text { with potassium }\end{array}$ & $\begin{array}{l}\text { Yes } \\
\text { Control: Bioglass } 45 S 5\end{array}$ & Sol-gel & $\begin{array}{l}\text { NHFB: normal human } \\
\text { fibroblast cell line }\end{array}$ & Direct & $\begin{array}{l}\text { Cell viability: CCK-8 assay } \\
\text { Cell-cycle analysis: Flow cytometer } \\
\text { Cell differentiation: ELISA } \\
\text { (anti-OCN) and ALP activity assay }\end{array}$ & $\begin{array}{l}\text { Cell viability: no differences. } \\
\text { Cell-cycle analysis: MBG did not } \\
\text { have any role in cell cycle } \\
\text { dose-dependency. }\end{array}$ \\
\hline $\begin{array}{l}\text { Wang-- } \\
2017 \text { [72] }\end{array}$ & $\begin{array}{l}\text { Bone } \\
\text { regeneration }\end{array}$ & $\begin{array}{l}\text { MBG (no information on the } \\
\text { composition of the MBG) } \\
\text { functionalized with } \\
\text { amino groups }\end{array}$ & $\begin{array}{l}\text { No } \\
\text { Control: } \\
\text { conventional MBG }\end{array}$ & Sol-gel & $\begin{array}{l}\text { MC3T3-E1: mouse } \\
\text { osteoblast cell line }\end{array}$ & Direct & $\begin{array}{l}\text { Cell adhesion: CLSM } \\
\text { Cell viability: CCK-8 assay } \\
\text { Cell differentiation: ALP activity } \\
\text { assay, Luciferase assay (RUNX-2) } \\
\text { and qRT-PCR analysis } \\
(\text { GAPDH, OCN, OPN) }\end{array}$ & $\begin{array}{l}\text { Better cell adhesion with } \\
\text { amino-MBGs than with } \\
\text { conventional MBGs. } \\
\text { Both MBGs with or without } \\
\text { adjuvant promote osteoblastic } \\
\text { differentiation. }\end{array}$ \\
\hline $\begin{array}{l}\operatorname{Xin}_{2017}[73] \\
\end{array}$ & $\begin{array}{l}\text { Bone } \\
\text { regeneration }\end{array}$ & $\begin{array}{l}\text { Nano MBG80S }\left(80 \mathrm{SiO}_{2}:\right. \\
\left.16 \mathrm{CaO}: 4 \mathrm{P}_{2} \mathrm{O}_{5}\right)(\mathrm{MBGN})+ \\
\text { methacrylicanhydride and } \\
\text { gelatin (GelMA-G) } \\
\text { (adjuvants) }\end{array}$ & $\begin{array}{l}\text { No } \\
\text { Blank control }\end{array}$ & Not indicated & $\begin{array}{l}\text { MC3T3-E1: mouse } \\
\text { osteoblast cell line }\end{array}$ & $\begin{array}{l}\text { Direct and } \\
\text { indirect }\end{array}$ & $\begin{array}{l}\text { Cell adhesion: SEM } \\
\text { Cell viability: CCK- } 8 \text { assay } \\
\text { Cell differentiation: } \\
\text { ALP activity assay }\end{array}$ & $\begin{array}{l}\text { GelMA-G-MBGN membrane } \\
\text { enhanced osteogenesis } \\
\text { differentiation. }\end{array}$ \\
\hline $\begin{array}{l}\text { Xue-- } \\
2017[74]\end{array}$ & $\begin{array}{l}\text { Bone } \\
\text { regeneration }\end{array}$ & $\begin{array}{l}\text { NanoMBG (NanoBGs) (No } \\
\text { information on the } \\
\text { composition of the MBG) } \\
\text { loaded with miRNA } \\
\text { (adjuvant) }\end{array}$ & $\begin{array}{l}\text { No } \\
\text { Blank control }\end{array}$ & Sol-gel & $\begin{array}{l}\text { hBMSCs: human bone } \\
\text { marrow mesenchymal } \\
\text { stem cells }\end{array}$ & Direct & $\begin{array}{l}\text { Cell morphology: Inverted } \\
\text { fluorescent microscopy } \\
\text { Cell adhesion: Inverted fluorescent } \\
\text { microscopy } \\
\text { Cell viability: Alamar Blue assay } \\
\text { and LIVE/DEAD assay } \\
\text { Cell differentiation: qRT-PCR } \\
\text { analysis (ALP, OPN, RUNX2) }\end{array}$ & $\begin{array}{l}\text { Good cell biocompatibility. } \\
\text { NanoBGs could efficiently deliver } \\
\text { miRNA to enhance osteogenic } \\
\text { differentiation. }\end{array}$ \\
\hline $\begin{array}{l}\mathrm{Yu}- \\
2017 \text { [75] }\end{array}$ & Gene delivery & $\begin{array}{l}\mathrm{MBG} 80 \mathrm{~S}\left(80 \mathrm{SiO}_{2}: 16 \mathrm{CaO}:\right. \\
\left.4 \mathrm{P}_{2} \mathrm{O}_{5}\right) \text { and silica } \\
\text { nanoparticles }\end{array}$ & $\begin{array}{l}\text { No } \\
\text { Control: commercial } \\
\text { transfection reagent } \\
\text { PEI 25K and LIPO300 }\end{array}$ & Sol-gel & $\begin{array}{l}\text { hBMSCs: human bone } \\
\text { marrow mesenchymal } \\
\text { stem cells }\end{array}$ & Direct & $\begin{array}{l}\text { Cell viability: LIVE/DEAD assay } \\
\text { Cell differentiation: } \\
\text { ALP activity assay }\end{array}$ & $\begin{array}{l}\text { NanoBGs revealed significantly } \\
\text { lower cytotoxicity than the } \\
\text { commercial transfection reagents. }\end{array}$ \\
\hline
\end{tabular}


Table 3. Cont.

\begin{tabular}{|c|c|c|c|c|c|c|c|c|}
\hline References & Aims & MBG Composition & $\begin{array}{l}\text { MBG Compared with } \\
\text { Conventional BG? }\end{array}$ & $\begin{array}{l}\text { MBG Elabos } \\
\text { Method }\end{array}$ & Type of Cells Used & $\begin{array}{l}\text { Culture Setting } \\
\text { (Direct or Indi- } \\
\text { rect Contact) }\end{array}$ & $\begin{array}{l}\text { Techniques Used to Assess } \\
\text { Biocompatibility }\end{array}$ & Main Results \\
\hline $\begin{array}{l}\text { Cai- } \\
2018[76]\end{array}$ & $\begin{array}{l}\text { Bone } \\
\text { regeneration }\end{array}$ & $\begin{array}{l}\text { MBG (no information on the } \\
\text { composition of the MBG) }+ \\
\text { trapped BMP2 (adjuvant) }+ \\
\text { microspheres of chitosan } \\
\text { (adjuvant) (containing IL8) }\end{array}$ & $\begin{array}{l}\text { No } \\
\text { Blank control }\end{array}$ & Sol-gel & $\begin{array}{l}\text { rBMSCs: rat bone marrow } \\
\text { mesenchymal stem cells }\end{array}$ & Direct & $\begin{array}{l}\text { Cell viability: CCK- } 8 \text { assay } \\
\text { Cell differentiation: ALP activity } \\
\text { assay and qRT-PCR analysis } \\
(\text { RUNX-2, COL-1, OPN, } \\
\text { OCN, } \beta \text {-actin })\end{array}$ & $\begin{array}{l}\text { Below } 1 \mathrm{mg} / \mathrm{mL} \text {, microspheres } \\
\text { exhibited little cytotoxicity to } \\
\text { rBMSCs. }\end{array}$ \\
\hline $\begin{array}{l}\text { Covarrubias- } \\
2018 \text { [77] }\end{array}$ & $\begin{array}{l}\text { Bone } \\
\text { regeneration }\end{array}$ & $\begin{array}{l}\text { NanoMBG (nBGs) } \\
\text { (No information on the } \\
\text { composition of the MBG) + } \\
\text { chitosan/gelatin (CHT/Gel } \\
\text { 1:1) (adjuvant) }\end{array}$ & $\begin{array}{l}\text { Yes nMBG/CHT/Gel, } \\
\text { and nBG/CHT/Gel } \\
\text { bionano-composite } \\
\text { scaffolds }\end{array}$ & Sol-gel & $\begin{array}{l}\text { DPSCs: dental pulp } \\
\text { stem cells }\end{array}$ & Direct & $\begin{array}{l}\text { Cell viability: MTS assay } \\
\text { Cell differentiation: } \\
\text { ALP activity assay }\end{array}$ & $\begin{array}{l}\text { Cell viability and proliferation } \\
\text { decreased with the concentration of } \\
\text { nBGs (due to high calcium release); } \\
5 \% \text { nBGs allowed the highest cell } \\
\text { proliferation rate. }\end{array}$ \\
\hline $\begin{array}{l}\text { Fiorilli- } \\
2018[78]\end{array}$ & $\begin{array}{l}\text { Bone } \\
\text { regeneration }\end{array}$ & $\begin{array}{l}\mathrm{MBG} 85 \mathrm{~S}\left(85 \mathrm{SiO}_{2}: 15 \mathrm{CaO}\right) \\
\text { doped with strontium }\end{array}$ & $\begin{array}{l}\text { No } \\
\text { Control: polystyrene }\end{array}$ & $\begin{array}{l}\text { Sol-gel and } \\
\text { aerosol-spray } \\
\text { drying } \\
\text { method }\end{array}$ & $\begin{array}{l}\text { J774a.1, fibroblast cell line } \\
\text { L929, Saos-2 }\end{array}$ & $\begin{array}{l}\text { Direct and } \\
\text { indirect }\end{array}$ & $\begin{array}{l}\text { Cell viability: MTT assay } \\
\text { Cell differentiation: qRT PCR } \\
\text { analysis (ALP, COL-1, GAPDH, } \\
O P G, R A N K L, S P A R C)\end{array}$ & $\begin{array}{l}\text { Good biocompatibility: reduction } \\
\text { of the inflammatory response and } \\
\text { stimulation of the pro-osteogenic } \\
\text { genes' expression. }\end{array}$ \\
\hline $\begin{array}{l}\text { Gómez-Cerezo } \\
\text {-2018 [79] }\end{array}$ & $\begin{array}{l}\text { Bone } \\
\text { regeneration }\end{array}$ & $\begin{array}{l}\text { MBG 75S } \\
\left(75 \mathrm{SiO}_{2}: 20 \mathrm{CaO}: 5 \mathrm{P}_{2} \mathrm{O}_{5}\right)\end{array}$ & $\begin{array}{l}\text { No } \\
\text { Control: without } \\
\text { material } \\
\text { Then, different doses of } \\
\text { MBG-75S }(0.5 \mathrm{mg} / \mathrm{mL} \text {, } \\
1 \mathrm{mg} / \mathrm{mL}, 2 \mathrm{mg} / \mathrm{mL})\end{array}$ & Sol-gel & $\begin{array}{l}\text { Human Saos-2, } \\
\text { osteoclast-like cells, murine } \\
\text { RAW } 264.7 \text { murine } \\
\text { macrophages }\end{array}$ & Direct & $\begin{array}{l}\text { Cell morphology: CLSM } \\
\text { Cell viability: Membrane integrity: } \\
\text { LDH: CytoTox-ONE TM } \\
\text { (Promega, G7890) } \\
\text { Apoptosis quantification and } \\
\text { cell-cycle analysis: Flow cytometry }\end{array}$ & $\begin{array}{l}\text { Cytotoxicity is dose dependent. } \\
\text { No inhibition of osteoclastogenesis. } \\
\text { Decrease of resorption activity. }\end{array}$ \\
\hline $\begin{array}{l}\mathrm{Hsu}- \\
2018[80]\end{array}$ & $\begin{array}{l}\text { Bone } \\
\text { regeneration }\end{array}$ & $\begin{array}{l}\text { Apatite-modified MBG } \\
\text { (no information on the } \\
\text { composition of the MBG): } \\
\text { MBGNFs (MBG nanofibers) } \\
\text { with PMMA and sodium } \\
\text { alginate (adjuvants) }\end{array}$ & No & Sol-gel & $\begin{array}{l}\text { MG-63: human } \\
\text { osteoblast-like }\end{array}$ & Direct & $\begin{array}{l}\text { Cell morphology: } \\
\text { Fluorescence microscopy } \\
\text { Cell differentiation: } \\
\text { Immunofluorescence } \\
\text { (BSP and OCN) }\end{array}$ & $\begin{array}{l}\text { Better cell adhesion but lower } \\
\text { viability with macroporous } \\
\text { microbeads containing MBG } \\
\text { nanofibers than with glass beads. }\end{array}$ \\
\hline $\begin{array}{l}\text { Jia- } \\
2019[81]\end{array}$ & Osteoporosis & $\begin{array}{l}\text { Sr-MBG (Porous } \\
\text { strontium-incorporated } \\
\text { mesopore-bioglass) } \\
\text { MBG doped with } 5 \% \mathrm{Sr}\end{array}$ & $\begin{array}{l}\text { No } \\
\text { Control: MBG 80S } \\
\text { 80Si0 } 0_{2}: 15 \mathrm{CaO}: 5 \mathrm{P}_{2} \mathrm{O}_{5}\end{array}$ & Sol-gel & $\begin{array}{l}\text { hPDLc: human periodontal } \\
\text { ligament stem cells }\end{array}$ & Indirect & $\begin{array}{l}\text { Cell differentiation: } \\
\text { Remineralization (Alizarin Red } \\
\text { staining and quantification), WB } \\
\text { (hnRNPL, Setd2, H3K36me3, } \\
\text { P-AKT, AKT, P-CREB) and RT } \\
\text { qPCR analysis (hnRNPL, Setd2, } \\
\text { ALPL, RUNX-2, GAPDH) }\end{array}$ & $\begin{array}{l}\text { Sr-MBG scaffolds had visibly more } \\
\text { new bone formation and vascular } \\
\text { distribution in the healing area } \\
\text { than MBG scaffolds. More frequent } \\
\text { RUNX-2-positive cells were } \\
\text { detected in the presence of Sr while } \\
\text { the percentage of hnRNPL-positive } \\
\text { cells was less in Sr-MBG group. }\end{array}$ \\
\hline $\begin{array}{l}\text { Kumar- } \\
2019[82]\end{array}$ & $\begin{array}{l}\text { Bone } \\
\text { regeneration }\end{array}$ & $\begin{array}{l}\mathrm{MBG} 64 \mathrm{~S}\left(64 \mathrm{SiO}_{2}: 31 \mathrm{CaO}:\right. \\
\left.5 \mathrm{P}_{2} \mathrm{O}_{5}\right)+ \text { surfactant }\end{array}$ & $\begin{array}{l}\text { No } \\
\text { No control at all }\end{array}$ & Sol-gel & $\begin{array}{l}\text { Human Saos-2: Sarcoma } \\
\text { osteogenic cells }\end{array}$ & Direct & $\begin{array}{l}\text { Cell viability: Membrane integrity: } \\
\text { LDH: CytoTox-ONE TM } \\
\text { (Promega, G7890) }\end{array}$ & $\begin{array}{l}\text { Cell proliferation was significantly } \\
\text { affected by the textural } \\
\text { characteristics, which is related to } \\
\text { dissolution rate of } \mathrm{Ca}, \mathrm{P} \text {, and } \mathrm{Si} \text {. }\end{array}$ \\
\hline $\begin{array}{l}\text { Mandakhbayar } \\
\text {-2019 [83] }\end{array}$ & $\begin{array}{l}\text { Bone } \\
\text { regeneration }\end{array}$ & $\begin{array}{l}\text { Sr-doped } \\
\left(85 \mathrm{SiO}_{2}: 10 \mathrm{CaO}: 5 \mathrm{SrO}\right) \text { and } \\
\mathrm{Sr}^{-} \text {free }\left(85 \mathrm{SiO}_{2}: 15 \mathrm{CaO}\right) \\
\text { nanobioactive glasses }\end{array}$ & $\begin{array}{l}\text { No } \\
\text { Blank control }\end{array}$ & Sol-gel & $\begin{array}{l}\text { DPSCs: dental pulp } \\
\text { stem cells }\end{array}$ & Indirect & $\begin{array}{l}\text { Cell cytotoxicity: WST-1, CCK-8 } \\
\text { assay and CLSM } \\
\text { Cell differentiation: ALP activity } \\
\text { and Alizarin Red staining and } \\
\text { quantification" }\end{array}$ & $\begin{array}{l}\text { Sr-NBC: high bioactivity, excellent } \\
\text { biodegradability, fast therapeutic } \\
\text { ion release, and high drug loading } \\
\text { capability, which potentiates its } \\
\text { application in dentin-pulp } \\
\text { complex regeneration therapy. }\end{array}$ \\
\hline
\end{tabular}


Table 3. Cont.

\begin{tabular}{|c|c|c|c|c|c|c|c|c|}
\hline References & Aims & MBG Composition & $\begin{array}{l}\text { MBG Compared with } \\
\text { Conventional BG? }\end{array}$ & $\begin{array}{l}\text { MBG Elabos } \\
\text { Method }\end{array}$ & Type of Cells Used & $\begin{array}{l}\text { Culture Setting } \\
\text { (Direct or Indi- } \\
\text { rect Contact) }\end{array}$ & $\begin{array}{l}\text { Techniques Used to Assess } \\
\text { Biocompatibility }\end{array}$ & Main Results \\
\hline $\begin{array}{l}\text { Pourshahrestani } \\
\text {-2018 [84] }\end{array}$ & Hemostasis & $\begin{array}{l}\text { Gallium-doped MBG } \\
\text { (no information on the } \\
\text { composition of the MBG) }\end{array}$ & $\begin{array}{l}\text { No } \\
\text { Control: other } \\
\text { hemostatic reagents }\end{array}$ & Sol-gel & $\begin{array}{l}\text { HDFs: human dermal } \\
\text { fibroblast cells }\end{array}$ & Direct & $\begin{array}{l}\text { Cell viability: MTT assay and } \\
\text { LIVE/DEAD assay }\end{array}$ & $\begin{array}{l}\text { No toxic effect. } \\
\text { Significant increase of viability. }\end{array}$ \\
\hline $\begin{array}{l}\mathrm{Qi}- \\
2018[85]\end{array}$ & $\begin{array}{l}\text { Bone } \\
\text { regeneration }\end{array}$ & $\begin{array}{l}\text { 3D printed borosilicate BG } \\
\left(6 \mathrm{Na}_{2} \mathrm{O}, 8 \mathrm{~K}_{2} \mathrm{O}, 2 \mathrm{MgO}, 6 \mathrm{SrO},\right. \\
222 \mathrm{CaO}, 36 \mathrm{~B}_{2} \mathrm{O}_{3}, 18 \mathrm{SiO}_{2}, \\
2 \mathrm{P}_{2} \mathrm{O}_{5} ; \text { mol. } \% \text { ) coated with } \\
\mathrm{MBG} \text { (no information on the } \\
\text { composition of the } \mathrm{MBG} \text { ) }\end{array}$ & $\begin{array}{l}\text { Yes } \\
\text { BG coated with MBG } \\
\text { compared with BG } \\
\text { without coating }\end{array}$ & 3D printing & $\begin{array}{l}\text { hBMSCs: human bone } \\
\text { marrow mesenchymal } \\
\text { stem cells }\end{array}$ & Direct & $\begin{array}{l}\text { Cell adhesion: SEM } \\
\text { Cell viability: CCK- } 8 \text { assay } \\
\text { Cell differentiation: ALP activity } \\
\text { assay and qRT-PCR analysis } \\
(\text { RUNX-2, OCN, COL1) }\end{array}$ & $\begin{array}{l}\text { Well-spread cell morphology. } \\
\text { Proliferation rates of BG-MBG > } \\
\text { BG scaffolds }(P<0.05) \text {. } \\
\text { ALP activity: } \\
\text { BG-MBG > BG }(P<0.05) \text {. } \\
\text { Upregulation of osteogenic-related } \\
\text { genes in cells grown on BG-MBG } \\
(P<0.05) \text {. }\end{array}$ \\
\hline $\begin{array}{l}\text { Shoaib- } \\
2018[86]\end{array}$ & Drug delivery & $\begin{array}{l}\text { MBG doped with potassium } \\
\text { (special composition related } \\
\text { to doping: } 49 \mathrm{SiO}_{2}: 20 \mathrm{CaO}: \\
20 \mathrm{Na}_{2} \mathrm{O}: 7 \mathrm{~K}_{2} \mathrm{O}: \\
4 \mathrm{P}_{2} \mathrm{O}_{5} \mathrm{~mol} \% \text { ) with variable } \\
\text { percentages was used as } \\
\text { filler in arginine and } \\
\text { starch-based PU matrices } \\
\text { (adjuvant) }\end{array}$ & $\begin{array}{l}\text { No } \\
\text { Different percentages } \\
\text { of MBG in the } \\
\text { nanocomposite }\end{array}$ & Sol-gel & $\begin{array}{l}\text { NHFB: normal human } \\
\text { fibroblast cell line }\end{array}$ & Direct & Cell viability: MTT assay & $\begin{array}{l}\text { Enhancement of cell adhesion. } \\
\text { No significant difference on } \\
\text { cell viability. }\end{array}$ \\
\hline $\begin{array}{l}\text { Zeng- } \\
2018[87]\end{array}$ & $\begin{array}{l}\text { Bone } \\
\text { regeneration }\end{array}$ & $\begin{array}{l}\mathrm{MBG} 80 \mathrm{~S}\left(80 \mathrm{SiO}_{2}: 16 \mathrm{CaO}:\right. \\
\left.4 \mathrm{P}_{2} \mathrm{O}_{5}\right) \text { functionalized with } \\
\text { amino groups (N-MBG) }\end{array}$ & $\begin{array}{l}\text { No } \\
\text { Blank control }\end{array}$ & Not indicated & $\begin{array}{l}\text { Rabbit BMSCs: bone } \\
\text { marrow mesenchymal } \\
\text { stem cells }\end{array}$ & $\begin{array}{l}\text { Direct and } \\
\text { indirect }\end{array}$ & $\begin{array}{l}\text { Cell viability: LIVE/DEAD assay } \\
\text { and MTT assay } \\
\text { Cell differentiation: ALP activity } \\
\text { assay and qRT-PCR analysis } \\
\text { (CaSR, RUNX-2, GAPDH, OPG, } \\
\text { RANKL, IL-10, Arg-1) }\end{array}$ & $\begin{array}{l}\text { Better cell viability and } \\
\text { differentiation with N-MBG. } \\
\text { Decreased gene expression after } \\
\text { NPS2143 (CaSR signaling pathway } \\
\text { inhibitor) treatment. }\end{array}$ \\
\hline $\begin{array}{l}\mathrm{Du}- \\
2019[88]\end{array}$ & $\begin{array}{l}\text { Bone } \\
\text { regeneration }\end{array}$ & $\begin{array}{l}\text { MBG (no information on the } \\
\text { composition of the MBG) }+ \\
\text { silk fibroin (adjuvant) } \\
\text { (MBG/SF) }\end{array}$ & $\begin{array}{l}\text { No } \\
\text { Control: MBG/PCL } \\
\text { scaffold }\end{array}$ & Sol-gel & $\begin{array}{l}\text { hBMSCs: human bone } \\
\text { marrow mesenchymal } \\
\text { stem cells }\end{array}$ & Direct & $\begin{array}{l}\text { Cell adhesion: SEM and CLSM } \\
\text { Cell viability: CCK-8 assay } \\
\text { Cell differentiation: ALP activity } \\
\text { assay and qRT-PCR analysis } \\
(B M P-2, O C N, O P N, B S P, C O L-1)\end{array}$ & $\begin{array}{l}\text { Better cell adhesion and } \\
\text { proliferation on MBG/SF } \\
\text { composite scaffold. }\end{array}$ \\
\hline $\begin{array}{l}\mathrm{Fu}- \\
2019[89]\end{array}$ & Drug delivery & $\begin{array}{l}\text { MBG (no information on the } \\
\text { composition of the MBG) }+ \\
\text { sodium alginate (SA) } \\
\text { (adjuvant) }\end{array}$ & $\begin{array}{l}\text { No } \\
\text { SA alone }\end{array}$ & 3D printing & $\begin{array}{l}\text { hBMSCs: human bone } \\
\text { marrow mesenchymal } \\
\text { stem cells }\end{array}$ & Direct & $\begin{array}{l}\text { Cell adhesion: CLSM } \\
\text { Cell viability: CCK-8 assay } \\
\text { Cell differentiation: ALP activity } \\
\text { assay and qRT-PCR analysis } \\
(O C N, \text { COL-1, BMP-2, BSP) }\end{array}$ & $\begin{array}{l}\text { More live cells, better cell } \\
\text { proliferation and differentiation } \\
\text { were observed on MBG/SA and } \\
\text { MBG/SA-SA scaffolds compared } \\
\text { to SA scaffolds. }\end{array}$ \\
\hline $\begin{array}{l}\text { Gómez-Cerezo } \\
\text {-2019 [90] }\end{array}$ & $\begin{array}{l}\text { Osteoporosis, } \\
\text { bone } \\
\text { regeneration } \\
\text { and drug } \\
\text { delivery }\end{array}$ & $\begin{array}{l}\mathrm{MBG58S}\left(58 \mathrm{SiO}_{2}:\right. \\
\left.37 \mathrm{CaO}: 5 \mathrm{P}_{2} \mathrm{O}_{5}\right)+ \\
\text { e-polycapro-lactone } \\
\text { (adjuvant) }\end{array}$ & $\begin{array}{l}\text { No } \\
\text { Blank control }\end{array}$ & Sol-gel & $\begin{array}{l}\text { Human Saos- } 2 \text { osteoblasts, } \\
\text { RAW-264.7 murine } \\
\text { macrophages }\end{array}$ & $\begin{array}{l}\text { Direct and } \\
\text { indirect }\end{array}$ & $\begin{array}{l}\text { Cell morphology: CLSM } \\
\text { Apoptosis quantification: } \\
\text { Flow cytometer } \\
\text { Cell-cycle analysis: Flow cytometer }\end{array}$ & $\begin{array}{l}\text { Zoledronic acid released from MBG } \\
\text { produced osteoblast apoptosis and } \\
\text { a delay of osteoblast proliferation } \\
\text { in a time-dependent way; caused } \\
\text { an inflammation and fibrosis. }\end{array}$ \\
\hline
\end{tabular}


Table 3. Cont

\begin{tabular}{|c|c|c|c|c|c|c|c|c|}
\hline References & Aims & MBG Composition & $\begin{array}{l}\text { MBG Compared with } \\
\text { Conventional BG? }\end{array}$ & $\begin{array}{l}\text { MBG Elabos } \\
\text { Method }\end{array}$ & Type of Cells Used & $\begin{array}{l}\text { Culture Setting } \\
\text { (Direct or Indi- } \\
\text { rect Contact) }\end{array}$ & $\begin{array}{l}\text { Techniques Used to Assess } \\
\text { Biocompatibility }\end{array}$ & Main Results \\
\hline $\begin{array}{l}\mathrm{Li}- \\
2019\end{array}$ & $\begin{array}{l}\text { Bone } \\
\text { regeneration } \\
\text { and drug } \\
\text { delivery }\end{array}$ & $\begin{array}{l}\text { Scaffold PLGA- MBG } \\
\left(\mathrm{SiO}_{2}-\mathrm{CaO}-\mathrm{P}_{2} \mathrm{O}_{5},\right. \\
\mathrm{Si} / \mathrm{Ca} / \mathrm{P}=80: 15: 5) \text { and } \\
\text { FTY/MBG-PLGA FTY } \\
\text { (adjuvant) }\end{array}$ & $\begin{array}{l}\text { No } \\
\text { Control: PLGA without } \\
\text { MBG }\end{array}$ & Sol-gel & $\begin{array}{l}\text { rBMSCs: rat bone marrow } \\
\text { mesenchymal stem cells and } \\
\text { HUVECs: human umbilical } \\
\text { vein endothelial cells }\end{array}$ & Indirect & $\begin{array}{l}\text { Cell adhesion: } \\
\text { Immunofluorescence } \\
\text { Cell proliferation: CCK-8 assay } \\
\text { Cell-cycle analysis: WB } \\
\text { (Erk1/2, p-Erk1/2) } \\
\text { Cell differentiation: ALP activity } \\
\text { assay, Alizarin Red S, crystal violet, } \\
\text { immunofluorescence (OCN), } \\
\text { qRT-PCR analysis ( } \beta \text {-actin, ALP, } \\
\text { OCN, BMP-2, Osterix, Hif- } 1 \alpha, \\
V E G F-A, C X C R 4), W B \\
\text { (Hif- } 1 \alpha \text { and } \beta \text {-actin) }\end{array}$ & $\begin{array}{l}\text { The scaffolds exhibited sustained } \\
\text { release of the bioactive lipids as } \\
\text { well as the calcium and silicon ions, } \\
\text { which were demonstrated to } \\
\text { broadly enhance biological } \\
\text { activities including the adhesion, } \\
\text { proliferation, and osteogenic } \\
\text { differentiation of rBMSCs as well } \\
\text { as the proliferative and in vitro } \\
\text { angiogenic ability of HUVECs. }\end{array}$ \\
\hline $\begin{array}{l}\text { Liu- } \\
2019[92]\end{array}$ & $\begin{array}{l}\text { Bone } \\
\text { regeneration }\end{array}$ & $\begin{array}{l}\text { MBG (no information on the } \\
\text { composition of the } \\
\text { MBG)-hydroxyapatite }+ \text { silk } \\
\text { fibroin (adjuvant) }\end{array}$ & $\begin{array}{l}\text { No } \\
\text { Silk fibroin alone }\end{array}$ & Sol-gel & $\begin{array}{l}\text { hMSCs: human } \\
\text { mesenchymal stem cells }\end{array}$ & Direct & $\begin{array}{l}\text { Cell morphology: FESEM } \\
\text { (field emission scanning electron } \\
\text { microscopy) } \\
\text { Cell viability: MTT assay } \\
\text { Cell differentiation: ALP activity } \\
\text { assay and qRT-PCR analysis } \\
\text { (COL-1, OCN, RUNX-2, GAPDH) }\end{array}$ & $\begin{array}{l}\text { Positive osteogenic differentiation } \\
\text { effect and upregulated osteoblastic } \\
\text { gene expression of samples } \\
\text { containing a high concentration of } \\
\text { hydroxyapatite. }\end{array}$ \\
\hline $\begin{array}{l}\text { Montalbano- } \\
2019[93]\end{array}$ & $\begin{array}{l}\text { Bone } \\
\text { regeneration }\end{array}$ & $\begin{array}{l}\text { NanoMBG_Sr4\% (dopant) + } \\
\text { Type I collagen (adjuvant), } \\
\text { with 4-StarPEG crosslinked } \\
\text { special composition of MBG } \\
\text { related to doping (Sr } / \mathrm{Ca} / \mathrm{Si} \\
=4 / 11 / 85 \% \mathrm{~mol})\end{array}$ & $\begin{array}{l}\text { No } \\
\text { Control: TCPS and } \\
\text { non-crosslinked } \\
\text { biomaterial samples }\end{array}$ & Sol-gel & $\begin{array}{l}\text { MG-63 human } \\
\text { osteoblast-like }\end{array}$ & $\begin{array}{l}\text { Direct and } \\
\text { indirect }\end{array}$ & $\begin{array}{l}\text { Cell adhesion: SEM } \\
\text { Cell viability: Alamar Blue assay } \\
\text { and indirect cytotoxicity assay } \\
\text { using "conditioned medium" }\end{array}$ & $\begin{array}{l}\text { Good cell adhesion, morphology, } \\
\text { and viability. }\end{array}$ \\
\hline $\begin{array}{l}\text { Pourshahrestani } \\
-2019[94]\end{array}$ & $\begin{array}{l}\text { Bone } \\
\text { regeneration }\end{array}$ & $\begin{array}{l}\text { AgMBG/POC: silver-doped } \\
\text { MBG 80S15C }\left(80 \mathrm{SiO}_{2} \text { : }\right. \\
\left.15 \mathrm{CaO}: 5 \mathrm{P}_{2} \mathrm{O}_{5}\right)+ \\
\text { poly }(1,8 \text { octanediol citrate) } \\
\text { (adjuvant) } \\
\mathrm{Si} / \mathrm{Ca} / \mathrm{P} / \mathrm{Ag}: 79 / 15 / 5 / 1: \\
1 \% \text { AgMBG } \\
\text { AgMBG/POC (wt. } \%): 5 / 95 ; \\
10 / 90 ; 20 / 80\end{array}$ & $\begin{array}{l}\text { No } \\
\text { Control: adjuvant alone }\end{array}$ & Sol-gel & $\begin{array}{l}\text { HDFs: human dermal } \\
\text { fibroblast cells }\end{array}$ & Direct & Cell viability: Alamar Blue assay & $\begin{array}{l}\text { Efficient antibacterial properties } \\
\text { while preserving a favorable } \\
\text { biocompatibility. }\end{array}$ \\
\hline $\begin{array}{l}\text { Terzopoulou } \\
-2019 \text { [95] }\end{array}$ & $\begin{array}{l}\text { Bone } \\
\text { regeneration }\end{array}$ & $\begin{array}{l}\mathrm{MBG} 80 \mathrm{~S}\left(80 \mathrm{SiO}_{2}: 16 \mathrm{CaO}:\right. \\
\left.4 \mathrm{P}_{2} \mathrm{O}_{5}\right) \text { doped with calcium } \\
\text { or strontium }+ \\
\text { polycapro-lactone }(\mathrm{PCL}) \\
\text { (adjuvant) }\end{array}$ & $\begin{array}{l}\text { No } \\
\text { Blank control }\end{array}$ & Sol-gel & $\begin{array}{l}\text { WJ-MSCs: human } \\
\text { Wharton's jelly-derived } \\
\text { mesenchymal stem cells }\end{array}$ & Indirect & $\begin{array}{l}\text { Cell adhesion: Fluorescence } \\
\text { microscopy } \\
\text { Cell viability: MTT assay }\end{array}$ & $\begin{array}{l}\text { No cytotoxicity observed after } 24 \mathrm{~h} \text {. } \\
\text { Osteoinductive additives in PCL } \\
\text { matrices facilitate the } \\
\text { differentiation. }\end{array}$ \\
\hline $\begin{array}{l}\text { Varini- } \\
2019[96]\end{array}$ & $\begin{array}{l}\text { Bone } \\
\text { regeneration }\end{array}$ & $\begin{array}{l}\text { Cerium-doped }(0 \text { to } 5 \%) \\
\text { MBG } 80 \mathrm{~S}\left(80 \mathrm{SiO}_{2}: 16 \mathrm{CaO}:\right. \\
\left.4 \mathrm{P}_{2} \mathrm{O}_{5}\right)+ \text { sodium alginate } \\
\text { (adjuvant) }\end{array}$ & $\begin{array}{l}\text { No } \\
\text { Blank control }\end{array}$ & Sol-gel & $\begin{array}{l}\text { MC3T3-E1: mouse } \\
\text { osteoblastic cells }\end{array}$ & $\begin{array}{l}\text { Direct and } \\
\text { indirect }\end{array}$ & $\begin{array}{l}\text { Cell viability: Alamar Blue assay } \\
\text { and membrane integrity: LDH: } \\
\text { CytoTox-ONE TM (Promega, G7890) } \\
\text { Cell differentiation: } \\
\text { ALP activity assay }\end{array}$ & $\begin{array}{l}\text { Better proliferation. No release of } \\
\text { cytotoxic agent. Differentiation } \\
\text { decreased with the amount } \\
\text { of cerium. }\end{array}$ \\
\hline
\end{tabular}


Table 3. Cont.

\begin{tabular}{|c|c|c|c|c|c|c|c|c|}
\hline References & Aims & MBG Composition & $\begin{array}{l}\text { MBG Compared with } \\
\text { Conventional BG? }\end{array}$ & $\begin{array}{l}\text { MBG Elabos } \\
\text { Method }\end{array}$ & Type of Cells Used & $\begin{array}{l}\text { Culture Setting } \\
\text { (Direct or Indi- } \\
\text { rect Contact) }\end{array}$ & $\begin{array}{l}\text { Techniques Used to Assess } \\
\text { Biocompatibility }\end{array}$ & Main Results \\
\hline $\begin{array}{l}\text { Wang- } \\
2019[17]\end{array}$ & $\begin{array}{l}\text { Bone } \\
\text { regeneration }\end{array}$ & $\begin{array}{l}\text { MBG and MBG-L (larger } \\
\text { pores) (no information on } \\
\text { the composition of the } \\
\text { MBG), FGF (fibroblast } \\
\text { growth factor) adsorbed } \\
\text { (adjuvant) }\end{array}$ & $\begin{array}{l}\text { No } \\
\text { Control: simple MBG }\end{array}$ & Sol-gel & $\begin{array}{l}\text { MC3T3-E1: mouse } \\
\text { osteoblast cell line }\end{array}$ & Direct & $\begin{array}{l}\text { Cell adhesion: laser microscope } \\
\text { Cell viability: CCK-8 assay } \\
\text { Cell differentiation: ALP activity } \\
\text { assay, Luciferase assay (RUNX-2) } \\
\text { and qRT-PCR analysis (RUNX-2, } \\
\text { OCN, OPN, GAPDH) }\end{array}$ & $\begin{array}{l}\text { Better cell adhesion, proliferation, } \\
\text { differentiation with large-pore } \\
\text { MBG. Adding FGF enhanced the } \\
\text { cell adhesion and differentiation } \\
\text { even more. }\end{array}$ \\
\hline $\begin{array}{l}\text { Wang-- } \\
2019[97]\end{array}$ & $\begin{array}{l}\text { Bone } \\
\text { regeneration }\end{array}$ & $\begin{array}{l}\text { MBG80S15C }\left(80 \mathrm{SiO}_{2}:\right. \\
\left.15 \mathrm{CaO}: 5 \mathrm{P}_{2} \mathrm{O}_{5}\right)+\mathrm{GO} \\
\text { (graphene oxide) (adjuvant) }\end{array}$ & $\begin{array}{l}\text { No } \\
\text { Control: MBG alone }\end{array}$ & Sol-gel & $\begin{array}{l}\text { rBMSCs: rat bone marrow } \\
\text { mesenchymal stem cells }\end{array}$ & $\begin{array}{l}\text { Direct and } \\
\text { indirect }\end{array}$ & $\begin{array}{l}\text { Cell morphology: SEM } \\
\text { Cell adhesion: SEM } \\
\text { Cell viability: CCK-8 assay } \\
\text { Cell differentiation: ALP activity } \\
\text { assay, RT-qPCR analysis (RUNX-2, } \\
A L P, O C N, C O L-1, V E G F, H I F-1 \alpha) \\
\text { and immunofluorescence }(\mathrm{OCN})\end{array}$ & $\begin{array}{l}\text { Better cell proliferation and } \\
\text { differentiation with the MBG } \\
\text { containing an adjuvant. }\end{array}$ \\
\hline $\begin{array}{l}\mathrm{Wu}- \\
2019 \text { [98] }\end{array}$ & $\begin{array}{l}\text { Bone } \\
\text { regeneration } \\
\text { in } \\
\text { osteoporosis }\end{array}$ & $\begin{array}{l}\mathrm{MBG} 80 \mathrm{~S}\left(80 \mathrm{SiO}_{2}: 16 \mathrm{CaO}:\right. \\
\left.4 \mathrm{P}_{2} \mathrm{O}_{5}\right)+ \text { sodium alginate } \\
\text { (SA) + gelatin (G); soaked } \\
\text { with calcitonin gene-related } \\
\text { peptide (CGRP) or Naringin } \\
\text { (NG) (adjuvants) }\end{array}$ & $\begin{array}{l}\text { No } \\
\text { Control: MBG and } \\
\text { MBG/SA/G }\end{array}$ & Sol-gel & $\begin{array}{l}\text { MG-63: human } \\
\text { osteoblast-like }\end{array}$ & $\begin{array}{l}\text { Direct and } \\
\text { indirect }\end{array}$ & $\begin{array}{l}\text { Cell adhesion: Inverted fluorescent } \\
\text { microscopy and SEM } \\
\text { Cell viability: CCK-8 assay } \\
\text { Cell differentiation: qRT-PCR } \\
\text { analysis }(R U N X-2, A L P, \\
\text { OPN, OCN) }\end{array}$ & $\begin{array}{l}\text { No difference in adhesion. } \\
\text { Drug adjuvants enhanced } \\
\text { proliferation and differentiation. }\end{array}$ \\
\hline $\begin{array}{l}\text { Zhang- } \\
2019[99]\end{array}$ & $\begin{array}{l}\text { Bone } \\
\text { regeneration }\end{array}$ & $\begin{array}{l}\text { MBG (no information on the } \\
\text { composition of the MBG) }\end{array}$ & $\begin{array}{l}\text { No } \\
\text { Blank control }\end{array}$ & Not indicated & $\begin{array}{l}\text { rBMSCs: rat bone marrow } \\
\text { mesenchymal stem cells }\end{array}$ & Direct & $\begin{array}{l}\text { Cell morphology: SEM and TEM } \\
\text { Cell proliferation: } \\
\text { Immunofluorescence (Ki67) } \\
\text { Cell differentiation: WB (ALP, } \\
\text { RUNX-2, OCN, BMP-2, B-actin, } \\
\text { Gli1, Smo), , qRT-PCR analysis (ALP, } \\
\text { RUNX-2, OCN, BMP-2, Gli1, Smo) } \\
\text { and RNA }\end{array}$ & $\begin{array}{l}\text { Bioactive glass-ceramic coating } \\
\text { promoted proliferation and } \\
\text { differentiation, and up regulated } \\
\text { the expression of } \\
\text { osteogenesis-related genes. }\end{array}$ \\
\hline $\begin{array}{l}\text { Zheng- } \\
2019 \text { [100] }\end{array}$ & $\begin{array}{l}\text { Bone } \\
\text { regeneration, } \\
\text { drug delivery }\end{array}$ & $\begin{array}{l}\text { Cu-MBGNs: MBG } 85 \mathrm{~S} \\
\left(85 \mathrm{SiO}_{2}: 15 \mathrm{CaO}\right) \text { doped with } \\
\text { copper }(0 \text { to } 10 \%)\end{array}$ & $\begin{array}{l}\text { No } \\
\text { Blank control }\end{array}$ & Sol-gel & $\begin{array}{l}\text { Mesenchymal stromal ST2 } \\
\text { cells derived from mouse } \\
\text { bone marrow of BC } 8 \text { mice }\end{array}$ & Indirect & Cell viability: CCK-8 assay & $\begin{array}{l}\text { Cytotoxicity of } \mathrm{Cu}-\mathrm{MBGNs} \text { was } \\
\text { related to the concentration of } \mathrm{Cu} \\
\text { ions as well as the dosage of } \\
\text { particles applied. }\end{array}$ \\
\hline $\begin{array}{l}\text { Berkmann- } \\
2020 \text { [101] }\end{array}$ & $\begin{array}{l}\text { Bone } \\
\text { regeneration }\end{array}$ & MBG $85 \mathrm{~S}\left(85 \mathrm{SiO}_{2}: 15 \mathrm{CaO}\right)$ & $\begin{array}{l}\text { No } \\
\text { Blank control }\end{array}$ & $\begin{array}{l}\text { Aerosol } \\
\text { spray-drying } \\
\text { method }\end{array}$ & $\begin{array}{l}\text { hMSCs: human } \\
\text { mesenchymal stem cells }\end{array}$ & Indirect & $\begin{array}{l}\text { Cell viability: PrestoBlue, LDH } \\
\text { Cell counting: DAPI test. } \\
\text { Cell differentiation: } \\
\text { Alizarin-Red staining }\end{array}$ & $\begin{array}{l}\text { Ionic dissolution products amplify } \\
\text { the osteogenic differentiation } \\
\text { of hMSCs. }\end{array}$ \\
\hline $\begin{array}{l}\text { Chitra- } \\
2020[102]\end{array}$ & $\begin{array}{l}\text { Bone } \\
\text { regeneration }\end{array}$ & $\begin{array}{l}\mathrm{MBG} 45 \mathrm{~S} 5\left(45 \mathrm{SiO}_{2}: 24.5 \mathrm{CaO}:\right. \\
\left.24.5 \mathrm{Na}_{2} \mathrm{O}: 6 \mathrm{P}_{2} \mathrm{O}_{5}\right): \\
\text { crystalline phase: } \\
\mathrm{Na}_{2} \mathrm{Ca}_{2} \mathrm{Si}_{3} \mathrm{O}_{9} \text { and } \\
\mathrm{Na}_{2} \mathrm{Ca}_{3} \mathrm{Si}_{6} \mathrm{O}_{16}\end{array}$ & Yes & Sol-gel & $\begin{array}{l}\text { MG-63: human } \\
\text { osteoblast-like and PBMC: } \\
\text { human peripheral blood } \\
\text { mononuclear cell }\end{array}$ & Direct & Cell viability: MTT assay & $\begin{array}{l}\text { The probe sonication enriches } \\
\text { the biocompatibility. }\end{array}$ \\
\hline
\end{tabular}


Table 3. Cont

\begin{tabular}{|c|c|c|c|c|c|c|c|c|}
\hline References & Aims & MBG Composition & $\begin{array}{l}\text { MBG Compared with } \\
\text { Conventional BG? }\end{array}$ & $\begin{array}{l}\text { MBG Elabos } \\
\text { Method }\end{array}$ & Type of Cells Used & $\begin{array}{l}\text { Culture Setting } \\
\text { (Direct or Indi- } \\
\text { rect Contact) }\end{array}$ & $\begin{array}{l}\text { Techniques Used to Assess } \\
\text { Biocompatibility }\end{array}$ & Main Results \\
\hline $\begin{array}{l}\text { Mocquot } \\
-2020[21]\end{array}$ & $\begin{array}{l}\text { Bone } \\
\text { regeneration }\end{array}$ & $\begin{array}{l}\mathrm{MBG} 75 \mathrm{~S}\left(75 \mathrm{SiO}_{2}: 15 \mathrm{CaO}:\right. \\
\left.10 \mathrm{P}_{2} \mathrm{O}_{5}\right)\end{array}$ & $\begin{array}{l}\text { No } \\
\text { Blank control }\end{array}$ & Sol-gel & $\begin{array}{l}\text { hDPCs: human dental pulp } \\
\text { cells }\end{array}$ & Indirect & $\begin{array}{l}\text { Cell morphology: CLSM } \\
\text { Cell viability: Alamar Blue assay } \\
\text { Cytotoxicity: crystal violet test } \\
\text { Cell differentiation: ALP activity } \\
\text { assay and immunofluorescence } \\
\text { (OCN and DMP-1) }\end{array}$ & $\begin{array}{l}\text { The MBG showed no cytotoxicity, } \\
\text { good cytoskeletal architecture, cell } \\
\text { spreading and adhesion. }\end{array}$ \\
\hline $\begin{array}{l}\text { Montalbano } \\
-2020[103]\end{array}$ & Osteoporosis & $\begin{array}{l}\text { Nano MBG }\left(85 \% \mathrm{SiO}_{2}: 11 \%\right. \\
\mathrm{CaO}+4 \% \mathrm{Sr})+ \text { collagen } \\
\text { (adjuvant) }\end{array}$ & $\begin{array}{l}\text { No } \\
\text { Blank control }\end{array}$ & Sol-gel & $\begin{array}{l}\text { MG-63: human } \\
\text { osteoblast-like + SaOS-2: } \\
\text { human osteosarcoma cell } \\
\text { line }\end{array}$ & Direct & $\begin{array}{l}\text { Cell viability: Alamar Blue assay } \\
\text { Cell adhesion and morphology: } \\
\text { SEM }\end{array}$ & $\begin{array}{l}\text { The developed hybrid system } \\
\text { largely proved its biocompatibility } \\
\text { in presence of MG- } 63 \text { and } \\
\text { Saos- } 2 \text { cells. }\end{array}$ \\
\hline $\begin{array}{l}\text { Montes-Casado } \\
\text {-2020 [104] }\end{array}$ & Immunity & $\begin{array}{l}\text { NanoMBG } \\
(81.44 \% \mathrm{SiO} 2-18.6 \% \mathrm{CaO})\end{array}$ & $\begin{array}{l}\text { No } \\
\text { Control: cells without } \\
\text { NanoMBGs }\end{array}$ & Sol-gel & $\begin{array}{l}\text { Murine BMDCs: Bone } \\
\text { marrow-derived dendritic } \\
\text { cells + SR.D10 Th2 CD4+ } \\
\text { lymphocytes + DC2.4 } \\
\text { dendritic cells }\end{array}$ & Direct & $\begin{array}{l}\text { Cell differentiation: Flow } \\
\text { cytometry assays (FACS + } \\
\text { antigenic markers) } \\
\text { Cell inflammation: cytokine } \\
\text { expression: immunofluorescence } \\
\text { (FACS + cytokine markers) } \\
\text { Cell proliferation: CellTraceTM } \\
\text { Violet dye (FACS) } \\
\text { Apoptosis: Annexin V (FACS) } \\
\text { Cytotoxicity: CLSM }\end{array}$ & $\begin{array}{l}\text { NanoMBGs were both non-toxic } \\
\text { and non-inflammagenic for murine } \\
\text { lymphoid cells and myeloid DCs } \\
\text { despite their efficient intake by the } \\
\text { cells. }\end{array}$ \\
\hline $\begin{array}{l}\text { Pontremoli- } \\
2020[105]\end{array}$ & $\begin{array}{l}\text { Bon } \\
\text { regeneration }\end{array}$ & 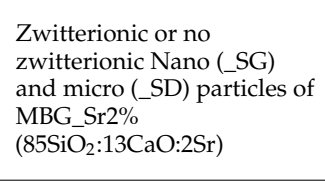 & $\begin{array}{l}\text { No } \\
\text { Control: cells without } \\
\text { MBGs }\end{array}$ & Sol-gel & $\begin{array}{l}\text { MC3T3-E1: mouse } \\
\text { osteoblast cell line }\end{array}$ & Direct & $\begin{array}{l}\text { Cell proliferation: MMT-test } \\
\text { Cytotoxicity: LDH } \\
\text { Cell differentiation: Alizarin Red } \\
\text { staining and quantification } \\
\text { Cell adhesion: SPS-PAGE and } \\
\text { Coomassie blue for visualization }\end{array}$ & $\begin{array}{l}\text { After zwitterionization the in vitro } \\
\text { bioactivity was maintained, no } \\
\text { cytotoxicity about Sr-MBG } \\
\text { particles. Zwitterionic Sr-MBGs } \\
\text { showed a significant reduction } \\
\text { of adhesion. }\end{array}$ \\
\hline $\begin{array}{l}\text { Wang-- } \\
2020[106]\end{array}$ & $\begin{array}{l}\text { Bone } \\
\text { regeneration }\end{array}$ & $\begin{array}{l}\text { Large-pore MBG } \\
\text { (no information on the } \\
\text { composition of the MBG) + } \\
\text { genistein (adjuvant) }\end{array}$ & $\begin{array}{l}\text { No } \\
\text { Control: MBG with } \\
\text { normal pore size }\end{array}$ & Sol-gel & $\begin{array}{l}\text { MC3T3-E1: mouse } \\
\text { osteoblast cell line }\end{array}$ & Direct & $\begin{array}{l}\text { Cell adhesion: } \\
\text { Fluorescence microscopy } \\
\text { Cell viability: CCK-8 assay } \\
\text { Cell differentiation: ALP activity } \\
\text { assay and qRT-PCR analysis } \\
\text { (OPN, GAPDH) }\end{array}$ & $\begin{array}{l}\text { Genistein is a molecule good for } \\
\text { cell attachment. MBG-L/G is the } \\
\text { better substrate for osteoblast } \\
\text { differentiation. }\end{array}$ \\
\hline $\begin{array}{l}\text { Zhou- } \\
2020[107]\end{array}$ & $\begin{array}{l}\text { Bone } \\
\text { regeneration }\end{array}$ & $\begin{array}{l}\text { MBG/SIS-P28: MBG } \\
\text { (no information on the } \\
\text { composition of the MBG) } \\
\text { doped with SIS (porcine } \\
\text { small intestinal submucosa) } \\
\text { + BMP2-related peptide P28 } \\
\text { MBG/SSS-H-P28 } \\
\text { (heparinized MBG/SIS) }\end{array}$ & $\begin{array}{l}\text { No } \\
\text { Control: MBG/SIS }\end{array}$ & Sol-gel & $\begin{array}{l}\text { MC3T3-E1: mouse } \\
\text { osteoblast cell line }\end{array}$ & Direct & $\begin{array}{l}\text { Cell proliferation: MTT-test } \\
\text { Cell viability: CLSM } \\
\text { Cell differentiation: ALP activity, } \\
\text { Alizarin Red staining) and } \\
\text { qRT-PCR analysis (GAPDH, } \\
\text { RUNX-2, OCN, OPN, ALP) }\end{array}$ & $\begin{array}{l}\text { MBG/SIS-H-P28 scaffolds exhibit a } \\
\text { much stronger ability to stimulate } \\
\text { bone regeneration. }\end{array}$ \\
\hline
\end{tabular}


Table 3. Cont

\begin{tabular}{|c|c|c|c|c|c|c|c|c|}
\hline References & Aims & MBG Composition & $\begin{array}{l}\text { MBG Compared with } \\
\text { Conventional BG? }\end{array}$ & $\begin{array}{l}\text { MBG Elabos } \\
\text { Method }\end{array}$ & Type of Cells Used & $\begin{array}{l}\text { Culture Setting } \\
\text { (Direct or Indi- } \\
\text { rect Contact) }\end{array}$ & $\begin{array}{l}\text { Techniques Used to Assess } \\
\text { Biocompatibility }\end{array}$ & Main Results \\
\hline $\begin{array}{l}\text { Zhou- } \\
2021[108]\end{array}$ & $\begin{array}{l}\text { Bone } \\
\text { regeneration }\end{array}$ & $\begin{array}{l}\text { MBGNs (no information on } \\
\text { the composition of the } \\
\text { mesoporous bioactive glass } \\
\text { nanoparticles) }\end{array}$ & $\begin{array}{l}\text { No } \\
\text { Control: gelatin } \\
\text { (Gel)/oxidized } \\
\text { chondroitin sulfate } \\
\text { (OCS) hydrogel } \\
\text { without MBGN }+ \\
\text { different MBGN } \\
\text { concentrations } \\
(0 \%, 5 \%, 10 \% \text { and } 15 \%)\end{array}$ & Sol-gel & $\begin{array}{l}\text { rBMSCs: rat bone marrow } \\
\text { mesenchymal stem cells }\end{array}$ & Direct & $\begin{array}{l}\text { Cell adhesion and spreading: } \\
\text { CLSM } \\
\text { Cell proliferation: CCK-8 assay } \\
\text { Cell viability: LIVE/DEAD assay } \\
\text { Cell differentiation: } \\
\text { Immunostaining (RUNX-2), ALP } \\
\text { activity assay, qRT-PCR analysis } \\
\text { (OCN, RUNX-2, OPN, COL-1), WB } \\
\text { (OCN, OPN), Immunofluorescence } \\
\text { (OPN) and Alizarin Red staining }\end{array}$ & $\begin{array}{l}\text { Presence of MBGNs enhanced } \\
\text { proliferation of BMSCs and } \\
\text { osteogenic differentiation of } \\
\text { BMSCs grown on } \\
\text { Gel/OCS/MBGN } \\
\text { hydrogel surfaces. }\end{array}$ \\
\hline
\end{tabular}

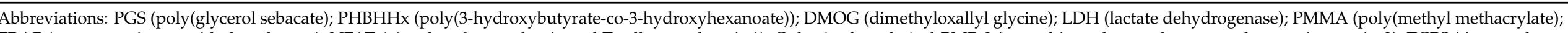

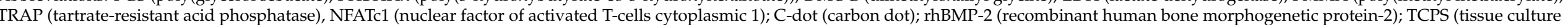

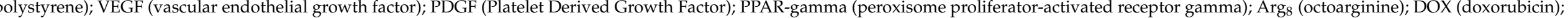

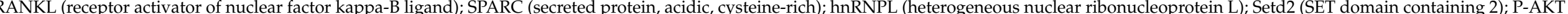

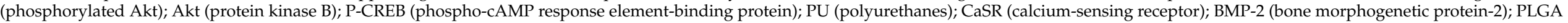

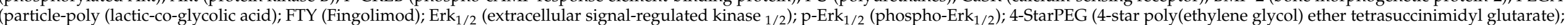

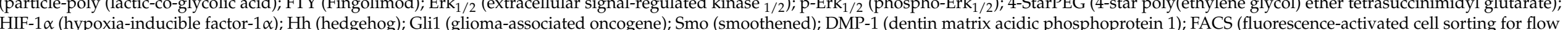
cytometry). 


\subsection{Control Group Used to Compare the Biocompatibility of Mesoporous Bioactive Glasses (MBGs)}

A choice of suitable control groups provides the basis on which the relative performance of the materials can be compared. This choice is therefore fundamental to each study to affirm or refute differences in the effects of the MBG studied. The vast majority of articles describe the use of an equivalent MBG (same composition) as the control group but without doping and/or adjuvant and/or functionalization.

About $6 \%$ (four articles $[71,77,85,102]$ ) of MBGs used a conventional BG as the control group. Mainly, MBGs show a significantly better biocompatibility than conventional BGs. MBG scaffolds demonstrate notably better cell viability and differentiation [77]. The use of negative controls could also be of interest in order to establish the normal behavior of cells under the experimental conditions of each protocol.

\subsection{Study Characteristics}

\subsubsection{MBG Synthesis, Characteristics, and Application Areas}

The sol-gel process is a wet-chemistry technique widely used in the production of vitreous and ceramic materials. This synthesis technique allows control over the morphology (nano-, micro-, and macro-size) and composition of the resulting mesoporous materials by varying the process parameters or by carrying out additional treatment at the gel stage of the materials [109]. One of the advantages of the sol-gel method is the simplicity of the equipment necessary for synthesis.

Nevertheless, and in view of green chemistry, the sol-gel process for bioactive glasses synthesis requires inorganic acids as catalysts, which have adverse effects on health and the environment [110]. Recently, Dang et al. used a modified sol-gel method to successfully elaborate bioactive glasses with the composition of $70 \mathrm{SiO}_{2}-30 \mathrm{CaO}$ (mol.\%) and with no acid catalysts [111]. With regard to environmental protection and human health, environmentally friendly methods for mesoporous bioactive glasses elaboration are required following the trend of green chemistry.

Eighty-three percent of the MBGs studied were synthesized by the sol-gel process. More rarely, a synthesis assisted by an aerosol or aerogel method was reported (5\%), making it possible to produce ordered mesoporous microspheres with a high degree of sphericity and an ordered mesostructure [112]. These different techniques were found in articles describing micro- or nano-MBGs [66,69]. In general, the sol-gel process was found to be employed for all sizes and morphologies of MBG. Finally, in 6\% of cases, MBGs were synthesized by 3D printing via so-called additive manufacturing (Figure 3).

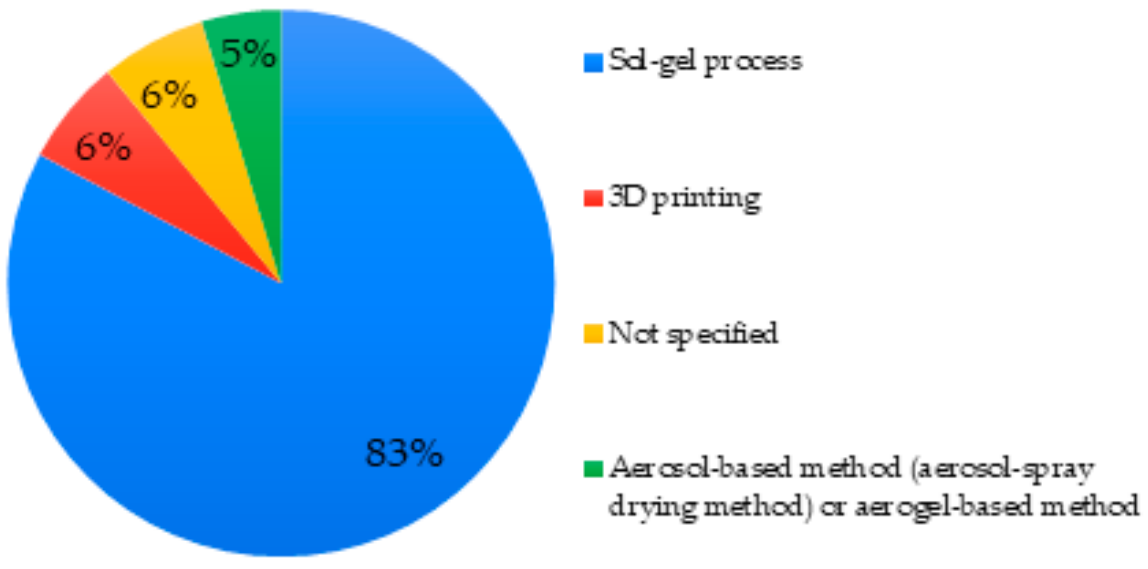

Figure 3. Mesoporous bioactive glass (MBG) synthesis methods used in studied articles.

Regarding the basic composition of MBG used, the great part of MBG used have a basic composition consisting of $\mathrm{SiO}_{2}-\mathrm{CaO}-\mathrm{P}_{2} \mathrm{O}_{5}$ with variable proportions. These relative proportions regulate parameters such as surface area, pore volume, and pore size, and thus consequently influence the mesoporous properties of MBG [113]. 
The composition of the MBG was not specified in 35\% of cases, even in the associated references; in such cases, the assessment or the comparison of any effect of composition cannot be discussed. The compositions which returned most often (29\%) were the MBG 80S15C (80SiO $\left.2: 15 \mathrm{CaO}: 5 \mathrm{P}_{2} \mathrm{O}_{5}\right)$ and $80 \mathrm{~S} 16 \mathrm{C}\left(80 \mathrm{SiO}_{2}: 16 \mathrm{CaO}: 4 \mathrm{P}_{2} \mathrm{O}_{5}\right)$. More rarely, specific compositions related to doping $(10 \%)$ or $\mathrm{MBG}$ compositions $85 \mathrm{~S} 15 \mathrm{C}\left(85 \mathrm{SiO}_{2}: 15 \mathrm{CaO}\right)$ were found (Figure 4).

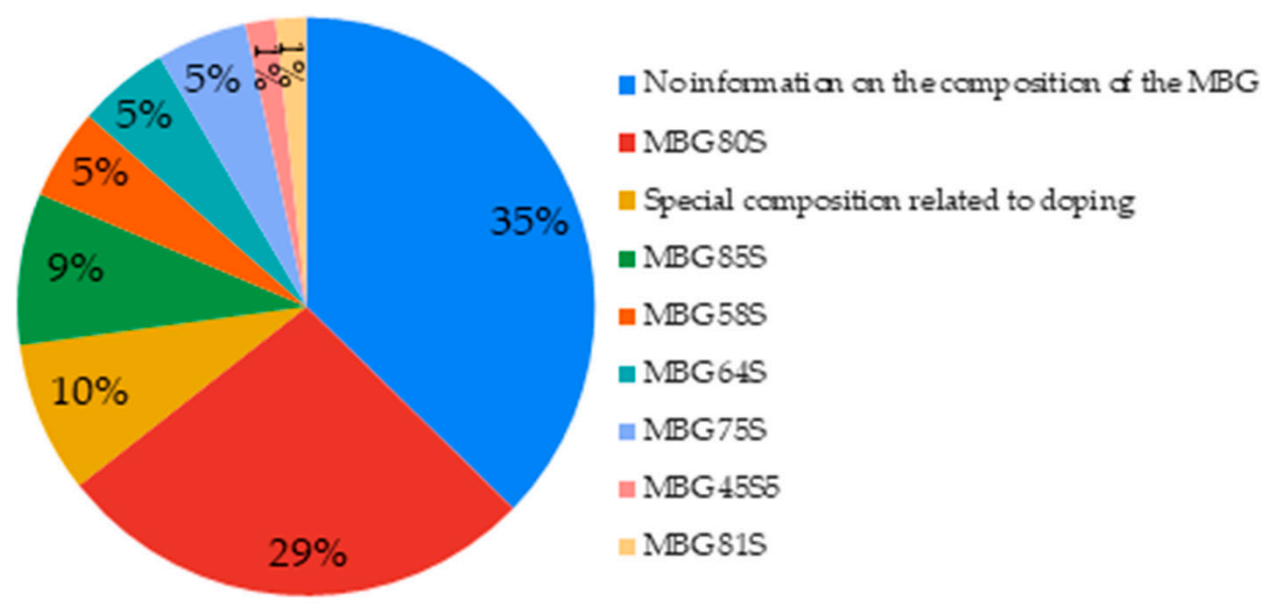

Figure 4. Basic compositions of MBGs used in the studied articles.

MBGs have several established medical applications such as bone regeneration [18], dentin remineralization [114], and much more. Studies are also underway to use mesoporous bioactive glasses for dental applications such as the prevention of prosthetic joint infections [115], as fillers in restorative materials, in direct contact with dentin and/or pulp tissues [21], dentinal sealing for the treatment of dentin hypersensitivity [116], coating for dental implants [115], and the treatment of periodontal diseases [117]. From the studies included, 74\% of articles used MBG for bone regeneration. More rarely, the applications were drug delivery, osteoporosis, or hemostasis. Gene delivery is also observed as one of the application areas of MBG providing a mechanism for the introduction of foreign genetic material (DNA, RNA, etc.) into host cells. This material will then migrate into the nucleus of the host cells and could induce modification on the gene expression profile. From another perspective, Zhou et al. assessed the inflammatory profile of some MBG nanoparticles incorporated in hybrid scaffolds using immunity cells [108].

\subsubsection{Doping and Adjuvants of Studied MBGs}

Due to high porosity, MBGs can be doped or they can be mixed with adjuvants like polymers to gain new properties [20]. It is also possible to ensure drug delivery [17].

The porosity of mesoporous bioactive glasses was exploited in 51\% of the articles by incorporating adjuvants inside the pores, such as growth factors [62]. It is also common to add them to polymers to create composites, for example, polycaprolactone [90,95]. In $28 \%$ of the cases, the MBGs were doped, either with a metal-like element or with amino groups. Almost systematically, adding a dopant decreases the level (mol.\%) of silicon in the MBG [55], see Figure 5.

In general terms, MBGs offer suitable platforms for drug/ion delivery which increases the range of possible uses in the biomedical field. For example, incorporation of strontium for the treatment of osteoporosis, cobalt to enhance the pro-angiogenic effects, and copper to improve angiogenesis and immune responses [118,119]. 


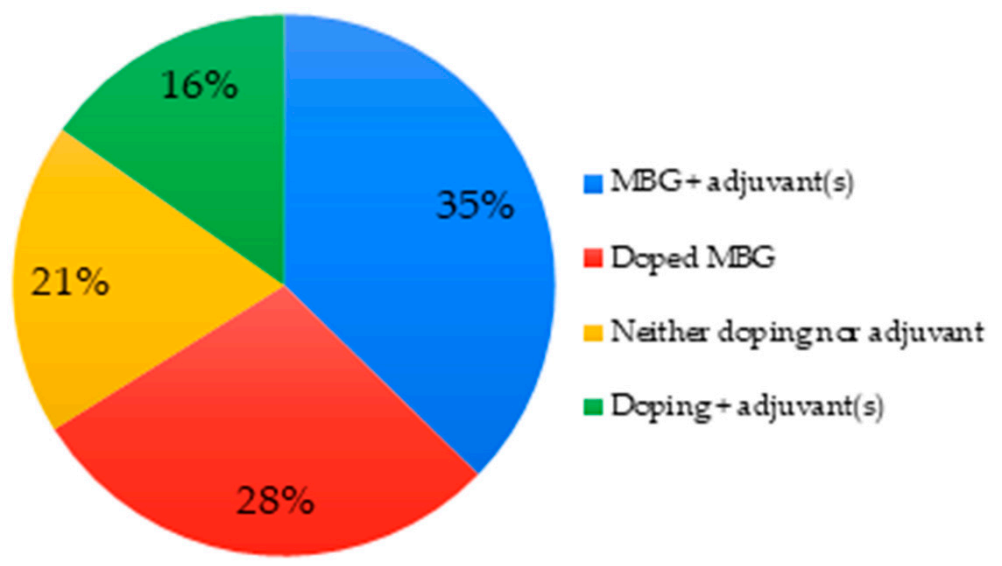

Figure 5. Doping and adjuvants of MBGs used in studied articles.

\subsection{Cells Characteristics}

Twenty-eight articles indicate the use of stem cells (Figure 6A) to perform biocompatibility tests in which about $3 / 4$ were BMSCs (bone marrow mesenchymal stem cells) derived from different mammals (human, rat, rabbit) (Figure 6B). Eighteen articles indicate the use of pre-osteoblastic, osteoblastic, or osteoblast-like cells (mostly from animal origin). Fiftysix percent used MC3T3-E1 type cells and 28\% used cells from MG-63 lines (Figure 6C). Fourteen articles indicate the use of cancer cells (Figure 6A); among them $43 \%$ were Saos-2 ("Sarcoma osteogenic") (Figure 6D). Eight articles indicate the use of fibroblasts cells, half were HDFs (human dermal fibroblast) cells (Figure 6E). From a clinical perspective, the cell type should be carefully chosen according to the targeted medical application.

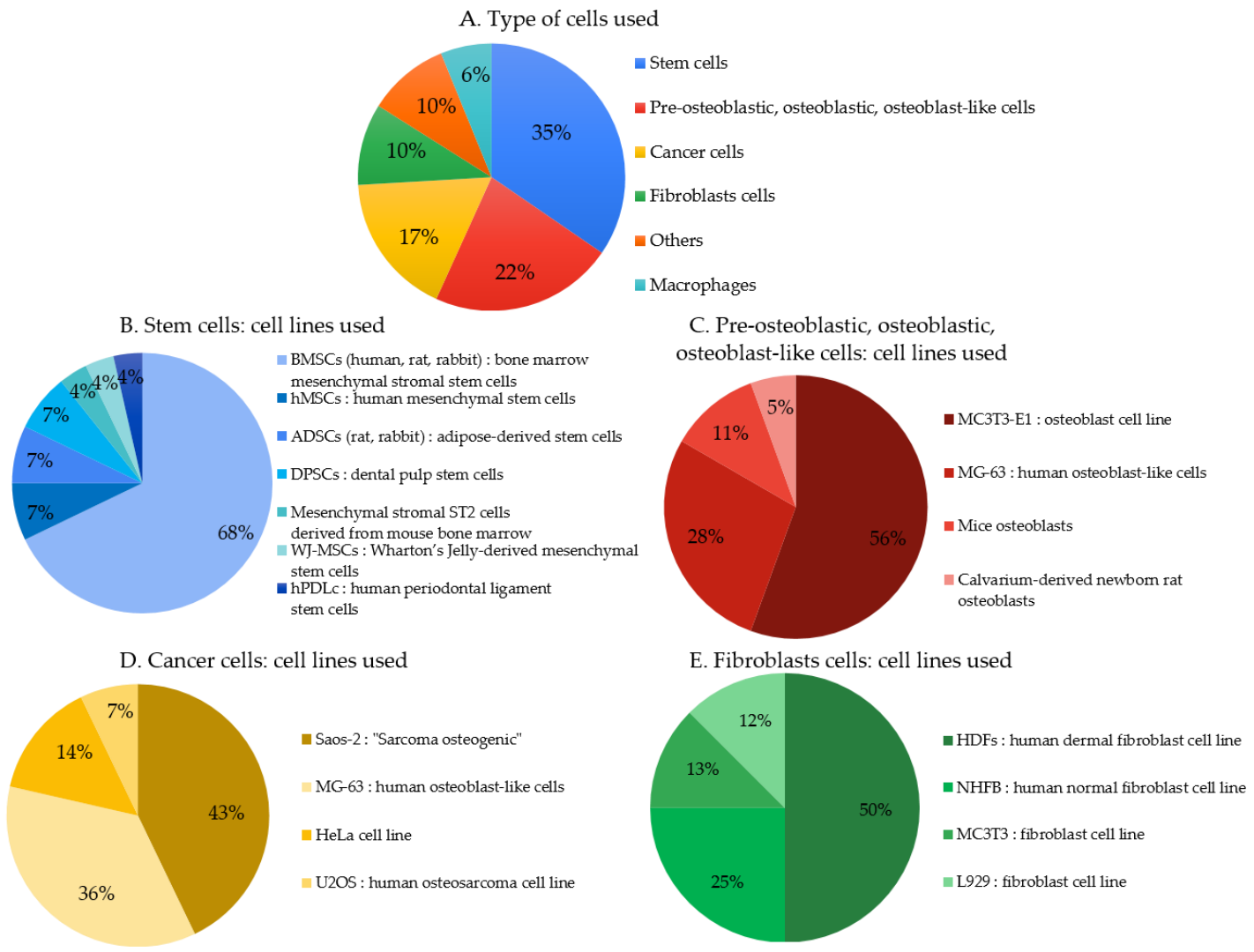

Figure 6. (A-E). Primary cells and cell lines used to assess cytocompatibility in the studied articles. 


\subsection{Techniques Used to Assess the MBG In Vitro Biocompatibility}

\subsubsection{Cell Morphology}

Morphological changes provide a first indication of the behavior of cells in contact with MBGs and can be studied using a variety of different techniques.

About $27 \%$ of articles investigated the modifications of cell morphology. Microscopy was the technique used by all, for example, scanning electron microscopy (SEM) was the primary choice, followed by confocal laser scanning microscopy (CLSM) and fluorescence microscopy, which was used in a lesser proportion of studies. Transmission electron microscopy (TEM) and inverted optical microscopy were also found to a lesser extent (Figure 7).

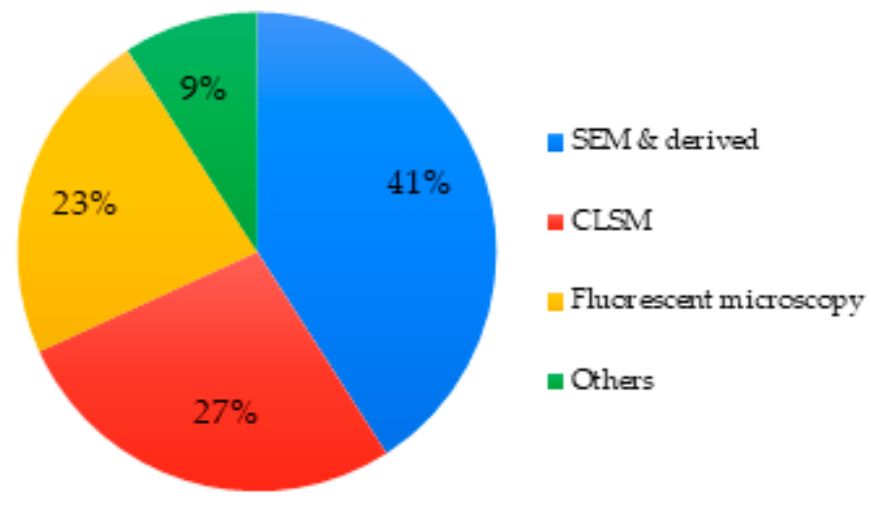

Figure 7. Techniques used to assess cell morphology of MBGs.

\subsubsection{Cell Adhesion/Attachment}

Cell adhesion/attachment is a dynamic process resulting from specific interactions between cell surface molecules and appropriate ligands [120] which is studied by imaging techniques. It is an essential parameter to validate the biocompatibility of a biomaterial.

About 38\% articles investigated the cell adhesion/attachment on the MBG surface. Once again, microscopy was a technique commonly used representing $90 \%$ of the studies. SEM and fluorescence microscopy were the most common. Optical density and SDS-PAGE combined with Coomassie Blue visualization were explored as alternative options in two separate articles (Figure 8) [49,105].

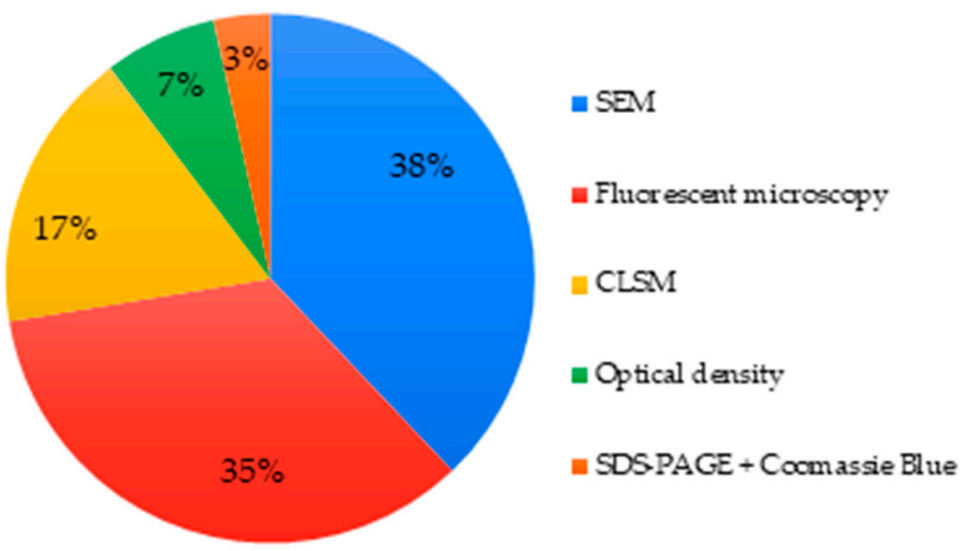

Figure 8. Techniques used to assess cell adhesion/attachment of MBGs.

\subsubsection{Cell Viability and Proliferation}

First of all, a cell viability assay is performed to assess the proportion of healthy and viable cells within a population. In a cell proliferation assay, the result is a precise measurement of the number of cells dividing [121]. A significant number of articles have confused the notions of cell viability, cell proliferation, and general cytotoxicity. The data have been reclassified clearly for this review. 
About $94 \%$ of articles investigated the cell viability and/or cell proliferation. A large panel of techniques were found for evaluating these parameters (Figure 9).
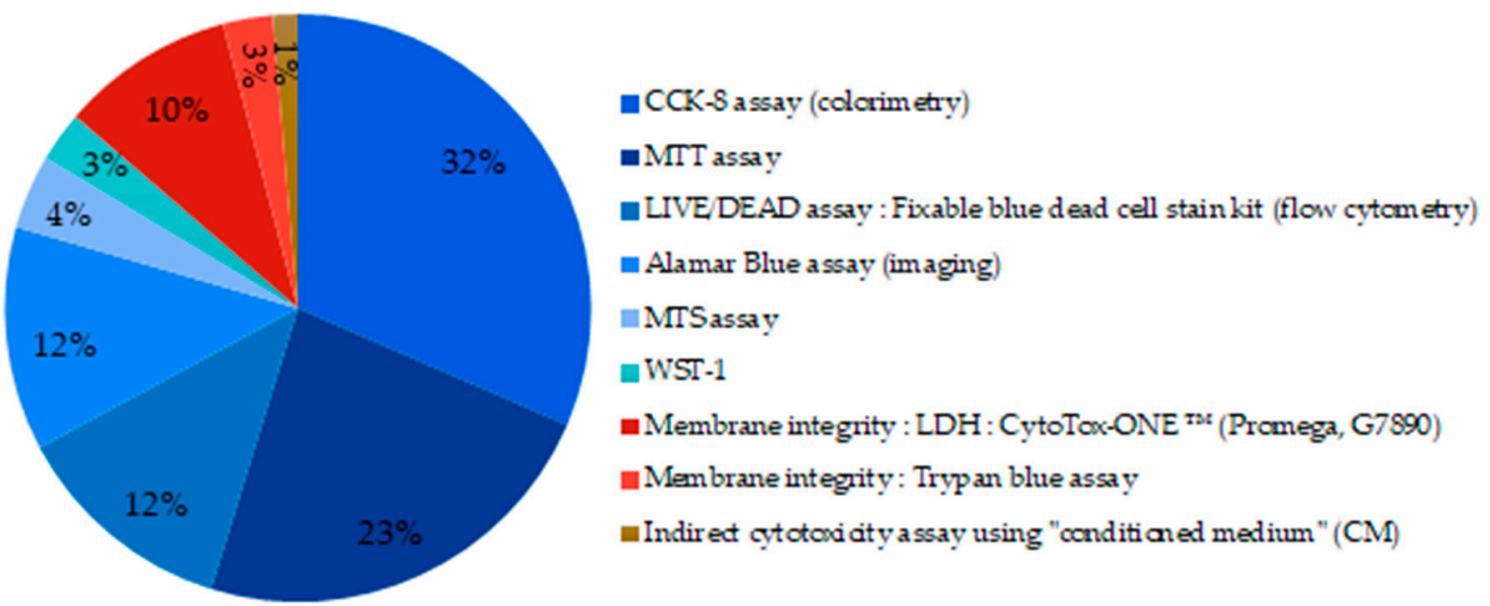

Figure 9. Techniques used to assess cell viability of MBGs. (blue part: metabolic assays; red part: membrane integrity measurement).

Eighty-six percent of the tests used were metabolic based assays. They are illustrated by the shaded blue portions in the graph (Figure 9). CCK-8 (Cell Counting Kit-8) assay uses a salt further reduced by active metabolic cells via dehydrogenase enzymes. The reduction product obtained is colored and its concentration is determined by colorimetric measurements. It is by far the technique most widely reported in the studies. The MTT (3-(4,5-dimethylthiazol-2-yl)-2,5-diphenyltetrazolium bromide) assay and the Alamar Blue assay that require different enzymes and reagents but follow the same oxide-reduction reaction were also reported. The LIVE/DEAD staining was used in $12 \%$ of the studies, it is a membrane integrity-based assay, and results are revealed by fluorescence measurement. Pintor et al. compared MTT assay to other cell viability assays and found that MTT and XTT (2,3-bis-(2-methoxy-4-nitro-5-sulfophenyl)-2H-tetrazolium-5-carboxanilide) assays do not induce over- or underestimation of the cell viability and were in at least moderate agreement with other cell viability assays when the root canal filling materials were screened [122].

\subsubsection{Apoptosis Quantification, Cell-Cycle Analysis}

Only three articles $[79,90,104]$ investigated apoptosis quantification by flow cytometry, and four articles $[71,79,90,91]$ investigated cell-cycle analysis using the same flow cytometry technique.

\subsubsection{Cell Differentiation}

Biomaterials and scaffolds play an essential role in guiding the target tissue growth, healing, and regeneration. That is why cell differentiation tests are essential for neo-tissue formation and could provide an indication of biomaterial bioactivity.

Forty-four articles (about 70\%) investigated cell differentiation. In order to do so, different cell markers had been used. A common method quantifies the alkaline phosphatase (ALP), an enzyme present in all differentiated tissues by colorimetric techniques in most of the investigated studies or by immunological techniques such as ELISA and western blot techniques in few studies $[62,99]$. Fluorescent or normal staining were also used to visualize ALP production and provided qualitative data [73,97]. qRT-PCR (quantitative reverse transcription PCR) targeting RNA coding for ALP is also a method to study cell proliferation. Other differentiation markers were found, like COL-1 (type I collagen), BMP-2 (bone morphogenetic protein-2), and GAPDH (glyceraldehyde phosphate dehydrogenase) used commonly as a reference gene (Figure 10). 


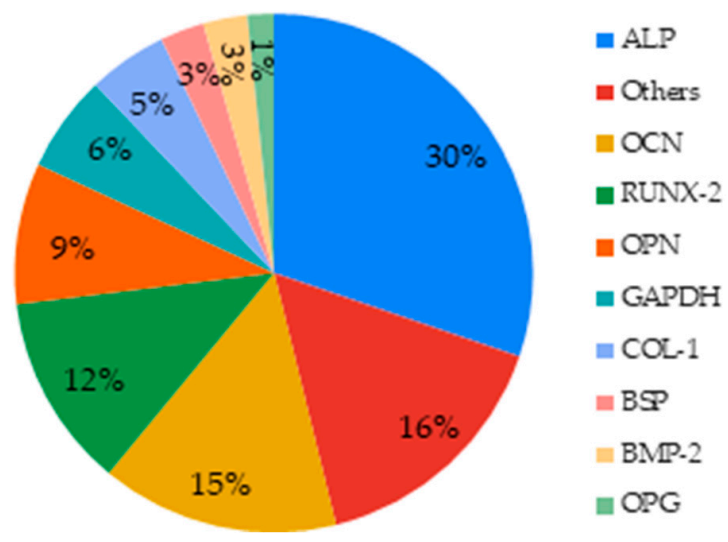

Figure 10. Markers studied to assess the effect of MBGs on cell differentiation.

In general terms, cell differentiation could be assessed more clearly in primary and undifferentiated cells due to their sensitivity and their potential for expression of key differentiation markers.

Table 4 lists the main specific tissue markers associated with bone regeneration and angiogenesis; two of the common most themes amongst the articles reviewed.

Table 4. Main cell differentiation markers and their application.

\begin{tabular}{cc}
\hline Topic of the Article & Studied Markers \\
\hline Bone regeneration & $\begin{array}{c}\text { Osteocalcin (OCN), runt-related transcription factor 2 (RUNX-2), } \\
\text { osteopontin (OPN), bone sialoprotein (BSP), osteoprotegerin (OPG) }\end{array}$ \\
\hline Angiogenesis & $\begin{array}{c}\text { Vascular endothelial growth factor (VEGF), hypoxia-inducible factor } \\
\text { 1-alpha (HIF1A), basic fibroblast growth factor (bFGF), } \\
\text { stromal-derived factor 1 (SDF-1) }\end{array}$ \\
\hline
\end{tabular}

There are different ways to evaluate and quantify those markers, qRT-PCR being the predominant one (64\%). Among immunological techniques in the studies selected, Western Blot (WB) was the most common (Figure 11).

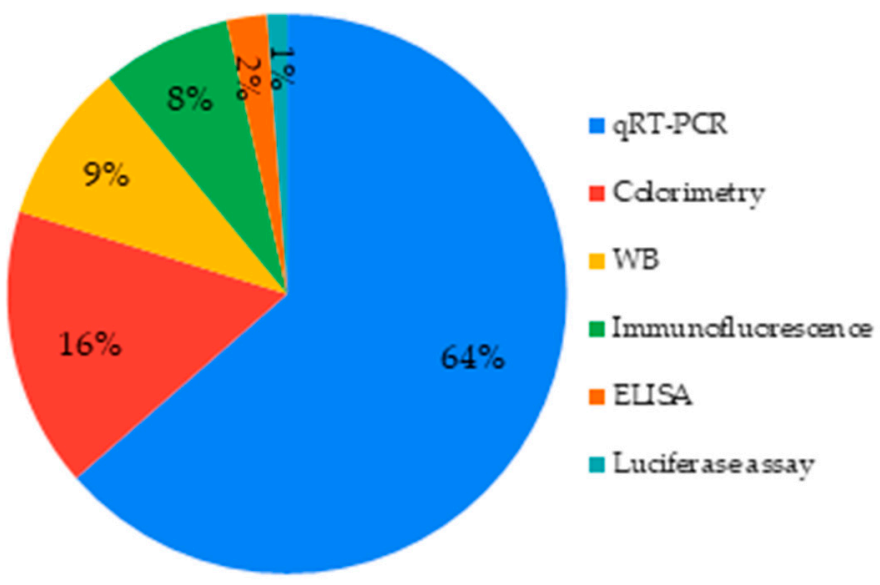

Figure 11. Techniques used to assess cell differentiation.

\subsection{Cell cultivation Setting (Direct and Indirect Contact)}

In certain clinical situations, MBGs or MBG-based materials do not make direct contact with cells, however, their dissolution products or leachates could reach targeted cells; this could explain the significant use of extraction techniques (indirect cultivation setting) when assessing cytocompatibility of materials [21,55,59,81,91,95,100,101]. In a test based on direct contact, the material sample is in physical contact with the cells; this system also 
has some clinical relevance. In this direct cultivation setting, test specimens are placed on top of an established cell monolayer as reported by [82] or on the top of the material surface [80]. According to the intended clinical application, the cultivation setting (direct or indirect) is selected. When direct contact is used, precautions should be taken to maintain the physiological balance of cells, on the other hand, the extraction method used to obtain the tested eluates should be suitable and allow an optimum of leachable materials in the indirect cultivation setting [123].

\section{Discussion}

The vast majority of MBGs studied were synthesized by the sol-gel process ( $83 \%$ of the studies, Figure 3). It is a process also widely used in the synthesis of conventional BGs because it not only allows fabrication of glasses according to different morphologies (fibers, powders, coatings, 3D porous scaffolds) but the synthesis is carried-out at a relatively low temperature with relatively simple equipment (in comparison with other synthetic methods such the melt quench technique). This process also makes it possible to offer a large surface area of active $\mathrm{Si}-\mathrm{OH}$ sites which can potentially be functionalized for more specific applications [124]. Indeed, the high mesoporosity and surface area of bioglasses prepared by sol-gel techniques enhance the kinetics of apatite formation and expand the compositional range [125]. The choice of synthesis of MBGs by sol-gel method seems to be the most relevant in medical applications because of its simplicity and the ability to tailor properties. Other synthesis methods exist such as the melt quench method or EISA (evaporation induced self-assembly). The first consists of melting silicon oxides at $1300^{\circ} \mathrm{C}$ and then cooling the molten glass quickly in a mold. However, high temperature results in the loss of residual surface silanols $\mathrm{Si}-\mathrm{OH}$ in favor of siloxane bonds $\mathrm{Si}-\mathrm{O}-\mathrm{Si}$ and the loss of particle porosity. Chitra et al. investigated the structural properties of a sol-gel-derived bioactive glass and found that the use of a probe sonication-assisted sol-gel method resulted in enhanced glass porosity and control over particle size [102]. Obtained nanoparticles were mesoporous in nature and exhibited a higher rate of biocompatibility and hydroxylapatite layer precipitation on the surface compared to conventional glass particles and micro glass particles [102]. EISA combines the sol-gel technique and supramolecular chemistry to obtain MBG particles with high surface area [32].

The introduction of 3D printing in the field of BGs, and especially, gel-derived BGs is showing great promise for expanding the applications of these materials. Indeed, fabrication of hierarchical MBG-based scaffolds is a challenge. In fact, mesopore size is almost three orders of magnitude lower than that of osteoblasts and, therefore, macroporosity must be somehow introduced in the final product in order to allow cell colonization and tissue in-growth [126].

Glass bioactivity is also affected by the glass composition. Bioactivity is the property of interacting with a tissue to drive its repair [2]. It is commonly evaluated by an index, $\mathrm{I}_{B}$, linked to the parameter, $t_{1 / 2}$, which is half the time necessary for the glass surface to be covered with cells.

$$
I_{B}=\frac{100}{t_{1 / 2}}
$$

In $38 \%$ of MBG whose composition was indicated in the articles, the proportion of $\mathrm{SiO}_{2}$ was greater than or equal to $80 \% \mathrm{~mol}$. This is explained by the increase in the surface area, pore volume, and pore size when the $\mathrm{SiO}_{2}$ content increases [113]. The high concentration of $\mathrm{SiO}_{2}$ plays a key role in bone metabolism and collagen synthesis. The most frequent composition for $\mathrm{MBG}$ comprised $\mathrm{SiO}_{2}: \mathrm{CaO}: \mathrm{P}_{2} \mathrm{O}_{5}$. The porosity increased when calcium oxide increased, compared with sodium oxide [32]. The compositions with high sodium interfered with the textural features by reducing the porosity because of the fusion of pores [10]. Porosity has a significant role at the interface with cellular membranes and could enhance bioactivity as a result of enhanced surface area [38]. Moreover, glasses with $\mathrm{CaO}$, $\mathrm{P}_{2} \mathrm{O}_{5}$, and $\mathrm{SiO}_{2}$ in their composition exhibit preferential layer formation on their surface involving the $\mathrm{Si}-\mathrm{OH}$ group formation including a heterogeneous nucleation of apatite [125]. 
Thanks to their porosity and their structure, MBGs offer a panel of possibilities in doping and addition of adjuvants according to the target application. These particular MBGs represented about $79 \%$ of the articles studied.

Most common dopants in MBGs were gallium, strontium, or copper [20,67,93]. Strontium is known to be a bone-seeking agent, improving stimulation of osteoblasts and having anabolic and anti-catabolic properties. It also has the ability to increase resistance to dissolution [127-129] with some antibacterial activity. Copper and gallium, on the other hand, improve biomineralization and amplify antimicrobial properties $[67,128,130]$. Wu et al. suggested the doping of MBG foams with europium (1-5 mol.\%) to fabricate luminescent scaffolds for biolabeling and clinical imaging applications without altering the bioactivity [131]. Europium-doped MBG scaffolds contributed to accelerated bone regeneration via the enhanced stimulation of new bone formation.

MBGs have also been investigated as controlled drug release systems. The combination of excellent surface properties and porosity, as well as the ability to be functionalized, allows them to act as release systems for antibiotics and/or osteogenic agents [132].

The review of Baino et al. focused on bioactive glass-based hierarchical materials and raises the issue of the potential health hazard related to the particle size of mesoporous nano-beads in implantable systems. In fact, silica nanoparticles of different sizes (250 and $500 \mathrm{~nm}$ ) penetrated into the cells (A549 and RAW264.7 types), being compartmentalized within endocytic vacuoles, and induced genotoxicity [38].

Regarding adjuvants and polymer-based materials, sodium alginate, chitosan, and polycaprolactone were the frequent polymers found in order to synthesize the scaffolds.

We noticed that, in most of these cases, cytotoxicity was directly associated with doping and/or adjuvants in a dose-dependent and time-dependent way. However, the literature reports that the introduction of dopants decreases the surface area and the pore volume of MBG, and consequently significantly decreases its mesoporous properties [113]. Thus, this property of mesoporosity of MBGs represents not only their strength but also their weakness by affecting some of their mechanical properties and the release of mesoporous components of nanometric size after their introduction in the human body [133].

The choices of the control groups are relevant for all of the articles studied. Some articles have gone further by studying the differences between MBGs and conventional BGs. The literature references significantly better biocompatibility results for MBGs compared to conventional BGs [113]. The results of biocompatibility assays emanating from several articles studied in this review draw the same conclusion, indicating that scaffold MBGs can promote osteogenic differentiation [72,79].

For the MBG cytocompatibility assessment, the majority of the investigated studies used different immortalized cell lines (about 75\% of the studies) such as MG-63 osteoblasts like cells $[80,98]$. The osteoblastic phenotype of MG-63 cells is particularly interesting for the study of bone regeneration [92]. Some studies have revealed that there are differences between established immortalized cell lines and primary cells in cellular response to the biomaterials in vitro [134,135]. Although established cell lines have the advantage of being immortal, available worldwide, and easy to grow, they remain distant from target cells and therefore do not allow the study of necessary markers (such as markers of bone remineralization). Primary cell cultures, on the other hand, are cells with a limited lifespan (because they differentiate after a few multiplications), but they are closest to the target tissues. This considerable advantage from primary cell lines makes it possible to study markers which cannot be studied with established cell lines, and to study bone remineralization in a more in-depth and relevant manner.

Regarding the cells, researchers used a large panel of different cell types. However, according to Johnson et al., there is a real difference in sensitivity of established cell lines that can differ even in controlled conditions [136]. The use of primary human cells or established lines of mammals are acceptable only if these cells are of sufficiently high quality to allow cell reproduction throughout the duration of the experiment, while maintaining their phenotypic characteristics. An official guideline could harmonize their use in the biomedi- 
cal research. Wilkesmann et al. compared the effect of the crystallized $45 \mathrm{~S} 5$ bioactive glasses on the viability and the osteogenic differentiation of different human osteogenic cells. Their data demonstrated that hOBs (human osteoblasts), BMSCs, and MG-63 cells were resistant to 45S5-BG induced cytotoxicity, while the viability of Saos-2, HOS (Homo sapiens bone osteosarcoma cells) and U2OS cells was significantly decreased. Moreover, ALP activity was enhanced in all tested cells except in U2OS cells upon $45 S 5$ co-cultivation [137]. Despite the difference between the textural properties of conventional BG and MBG (high porosity and high surface area of MBG) that could enhance cytocompatibility, the cell type used could affect the biological behavior of tested glasses. In general, and according to the clinical application, the use of primary human cells represents the most suitable standard but has some limitations due to patient variability (sex, age, physiological conditions, etc.) which must be taken into consideration. However, the use of cell lines could be more advantageous regarding the reproducibility and the standardization of the experimental conditions resulting in comparable results obtained from different studies $[138,139]$.

Only 41 articles (about $65 \%$ of the included studies) investigated cell morphology and/or the cell adhesion even though they are important parameters to evaluate biocompatibility. An appropriate choice of microscopy is relevant with SEM, CLSM, and fluorescence microscopy being well established in the field. However, optical techniques like optical imaging are often less precise and should be substituted or combined with one of the three techniques previously noted above. SEM allowed characterization of cell morphology and spreading, while CLSM allowed monitoring of cell colonization within scaffolds containing bioactive glasses. Some authors used more than one technique in order to provide different and complementary data.

Regarding cell viability or cell proliferation, 59 articles were found to have investigated them. Another relevant point is that, among these 59 articles, 36 confused the terms "cell viability" and "cell proliferation" and so that is why we had to treat both terms simultaneously in this review. Indeed, a cell viability test measures the ratio of living and dead cells in a population whereas a cell proliferation test assesses dividing cells [121]. Typically, using a LIVE/DEAD assay for cell proliferation is false, because it is only a cell viability test.

The different techniques used have all shown their efficiency for evaluating cell viability and proliferation. It is important to carefully choose the tests to be carried out, as there are many of them and each targets different cell processes. Trypan Blue, MTT, and $\mathrm{LDH}$ assays are the most common tests as they are inexpensive. When evaluating a new biomaterial, mostly reserved for bone regeneration, tests should be carried out over a comparatively longer timescale; a period of 28 days is usually required to cover the osteogenic differentiation needed to demonstrate bone remineralization, while shorter cultivation periods $(1,3$, or 7 days) are long enough to reveal cytotoxicity when investigating both bone and soft tissue behavior. In this case, the Alamar Blue assay, which is non-toxic, highly sensitive, and stable, seems to be the best candidate test and could be more widely used in the future for biomaterials cytotoxicity assessment [140]. Moreover, some techniques such as the MTT and MTS assays can be qualitative and quantitative. That is why it is interesting to use them for both cell proliferation and viability. Both MTT and MTS are colorimetric tests and based on mitochondrial activity enzymes. However, the main difference between MTT, MTS, and WST-1 tests is that MTT assay has an additional step associated with the solubilization of formazan crystals whereas MTS and WST-1 assay are not associated with the solubilization of formazan crystals. The limitation of the MTT assay is that it requires the destruction of the cells for the analysis, thus making it impossible to use the cells for other investigations, following the same cell population within the same assay. It is also more time consuming [141].

Apoptosis quantification and cell cycle analysis are trials to study cell viability and death in more detail (three articles). Thanks to these tests, it is possible to have more precise information on the phases involved in cell death in contact with biomaterials, and therefore, on the cytotoxicity of the latter. Regarding the analysis of the cell cycle, this 
test is commonly performed using flow cytometry and consists of measuring the content of cellular DNA using a fluorescent dye that binds to DNA. Binding is quantified by measurement of the strength of the fluorescent signal. This DNA content finally makes it possible to differentiate between the different phases of the cell cycle [142]. Regarding the quantification of apoptosis, most of the time and from the included studies, this test is also carried out using flow cytometry through the analysis of DNA fragmentation $[79,90,104]$.

Forty-four articles (about 70\%) investigated cell differentiation and 38 of them measured ALP activity. ALP is a marker found in all body tissues and the marker of early differentiation and extracellular matrix mineralization [143]. ALP activity revealed the differentiation potential of dental pulp cells after a short period (7 days) of contact with MBG [21]. In some articles, other markers were measured according to the target application as well as according to the cells studied (primary cells, established cell lines, cancer cells). The main markers used for bone regeneration were osteocalcin and osteopontin. Different angiogenesis factors such as VEGF were reported in these studies (Table 4). Figure 12 summarizes the methods used for the cytocompatibility assessment of mesoporous bioactive glasses and their medical applications.

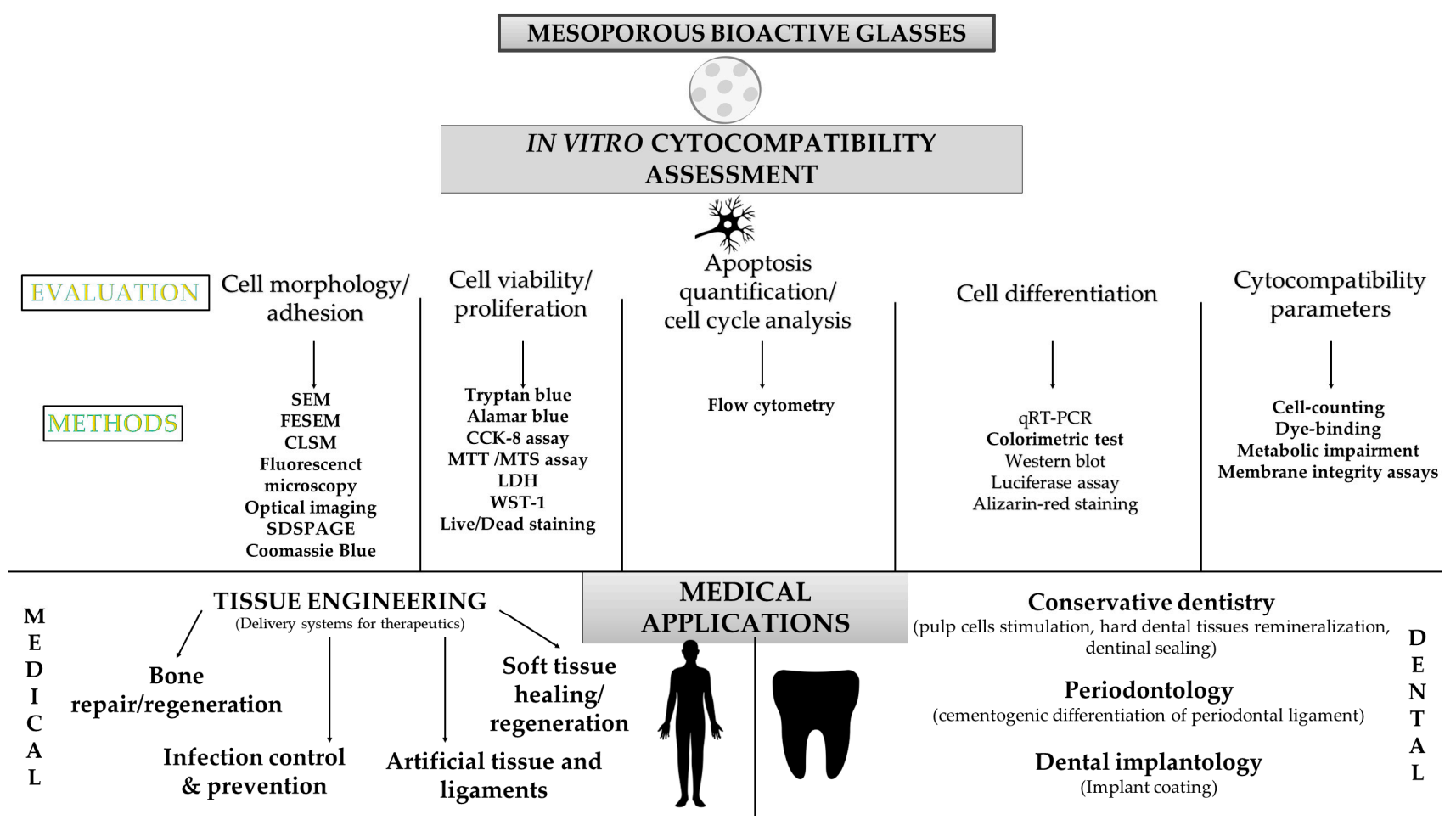

Figure 12. MBG cytocompatibility methodologies and their medical applications.

A broad spectrum of techniques were found to used, that is to say colorimetric techniques, immunological techniques (ELISA, western blot), and qRT-PCR (Figure 12). However, western blot allowed a semi-quantification, unlike ELISA, that enabled a real quantification and should be privileged when possible. Combining qRT-PCR (gene expression) and ELISA (proteins level) could be relevant to provide a whole transcriptomic and proteomic data.

Four articles were excluded because they only explored biocompatibility in vivo. However, some studies show that in vitro tests are more effective in discriminating the cytotoxic nature of the material than in vivo tests [144]. The review of Keong et al. showed that testing in vitro was useful to characterize cytotoxic effects of molecules released from a biomaterial, such as residual monomers, catalysts, etc. [145]. This explains why they concluded that, when evaluating any newly developed biomaterial, in vitro tests should be conducted prior to in vivo tests in order to minimize the risk to humans and animals. Furthermore, we 
strongly believe that the use of predictive and standard in vitro tests could reduce the use of animal experiments, the scientific limits and societal impacts of which are highly recognized.

International organization for standardization (ISO) recommendations would help increase the repeatability and comparability of in vitro cytotoxicity and cytocompatibility studies. According to the ISO 10,993 recommendations regarding medical devices [123], one of the criteria for biocompatibility is the absence of material toxicity to cells. Cytotoxicity methods recommended by this norm and by the ISO norm 7405 [146] (which specifies test methods for medical devices used in dentistry biological effects evaluation) are cell-counting, dye-binding, metabolic impairment, or membrane integrity assays. The investigation of two parameters would be more reliable than the use of only one protocol to assess cytocompatibility. According to the critical review of Mocquot et al., bioactive glass bioactivity ranged from reactivity and apatite formation to pulp cell stimulation enhancement [9]. Even though "bioactivity assessment" is more demanding than cytocompatibility assessment when BG behavior is investigated in vitro, the link between the two assessments should be taken in consideration for comprehensive risk assessment of such materials.

\section{Conclusions}

Biocompatibility in vitro ranks as one of the most important properties to investigate with regards to the behavior of biomaterials, such as MBG. The articles investigated in this review clearly show the importance of validating the biocompatibility of these materials. However, there is a real lack of standardization regarding the methodologies used for MBG cytocompatibility assessment. For MBGs, primary cells seem to be the most appropriate cell model for studying biocompatibility. Microscopy is an essential technique for studying morphology and cell adhesion. Cell viability and proliferation, although often confused, can be investigated by a variety of relevant and predictive techniques. In some cases, it is interesting to go further by studying cytotoxicity in more depth by analyzing the cell cycle and quantifying apoptosis. Cell differentiation can be studied via the detection of certain precise markers by qRT-PCR which is the most frequently used and most precise technique. A multiparametric approach for all the tests (metabolic or not) could be interesting to improve the evaluation relevance and sensitivity. The standardization of all tests necessary to be performed to validate the biocompatibility of MBGs is a crucial point which will have to be further investigated in order to eliminate inconsistencies and, therefore, sources of error when comparing studies and unnecessary expenditure of time.

Author Contributions: Methodology, C.M. and N.A.; investigation, M.V. and M.S.; writing—original draft preparation, M.V. and M.S.; writing-review and editing, C.C., C.M. and N.A.; supervision, N.A., B.G. and P.C. All authors have read and agreed to the published version of the manuscript.

Funding: This research received no external funding.

Institutional Review Board Statement: Not applicable.

Informed Consent Statement: Not applicable.

Data Availability Statement: Not applicable.

Acknowledgments: The authors are very grateful to Christopher Lovell (Stoke-on-Trent, ST4 7LQ, UK) for his assistance with the English language revision.

Conflicts of Interest: The authors declare no conflict of interest.

\section{References}

1. Hench, L.L. The Story of Bioglass ${ }^{\circledR}$. J. Mater. Sci. Mater. Med. 2006, 17, 967-978. [CrossRef] [PubMed]

2. Donaruma, L.G. Definitions in Biomaterials. J. Polym. Sci. B Polym. Lett. Ed. 1988, 26, 414. [CrossRef]

3. Jones, J.R. Review of Bioactive Glass: From Hench to Hybrids. Acta Biomater. 2013, 9, 4457-4486. [CrossRef] [PubMed]

4. Zamet, J.S.; Darbar, U.R.; Griffiths, G.S.; Bulman, J.S.; Bragger, U.; Burgin, W.; Newman, H.N. Particulate BioglassR as a Grafting Material in the Treatment of Periodontal Intrabony Defects. J. Clin. Periodontol. 1997, 24, 410-418. [CrossRef]

5. Braem, A.; Mattheys, T.; Neirinck, B.; Čeh, M.; Novak, S.; Schrooten, J.; Van der Biest, O.; Vleugels, J. Bioactive Glass-Ceramic Coated Titanium Implants Prepared by Electrophoretic Deposition. Mater. Sci. Eng. C 2012, 32, 2267-2273. [CrossRef] 
6. Van Oirschot, B.A.J.A.; Alghamdi, H.S.; Närhi, T.O.; Anil, S.; Al Farraj Aldosari, A.; van den Beucken, J.J.J.P.; Jansen, J.A. In Vivo Evaluation of Bioactive Glass-Based Coatings on Dental Implants in a Dog Implantation Model. Clin. Oral Impl. Res. 2014, 25, 21-28. [CrossRef]

7. Pourshahrestani, S.; Kadri, N.A.; Zeimaran, E.; Towler, M.R. Well-Ordered Mesoporous Silica and Bioactive Glasses: Promise for Improved Hemostasis. Biomater. Sci. 2019, 7, 31-50. [CrossRef]

8. Earl, J.S.; Leary, R.K.; Muller, K.H.; Langford, R.M.; Greenspan, D.C. Physical and Chemical Characterization of Dentin Surface Following Treatment with NovaMin Technology. J. Clin. Dent. 2011, 22, $62-67$.

9. Mocquot, C.; Attik, N.; Pradelle-Plasse, N.; Grosgogeat, B.; Colon, P. Bioactivity Assessment of Bioactive Glasses for Dental Applications: A Critical Review. Dent. Mater. 2020, 36, 1116-1143. [CrossRef]

10. Yan, X.; Yu, C.; Zhou, X.; Tang, J.; Zhao, D. Highly Ordered Mesoporous Bioactive Glasses with Superior In Vitro Bone-Forming Bioactivities. Angew. Chem. Int. Ed. 2004, 43, 5980-5984. [CrossRef]

11. Fernando, D.; Attik, N.; Cresswell, M.; Mokbel, I.; Pradelle-Plasse, N.; Jackson, P.; Grosgogeat, B.; Colon, P. Influence of Network Modifiers in an Acetate Based Sol-Gel Bioactive Glass System. Microporous Mesoporous Mater. 2018, 257, 99-109. [CrossRef]

12. Pérez-Pariente, J.; Balas, F.; Román, J.; Salinas, A.J.; Vallet-Regí, M. Influence of Composition and Surface Characteristics on the in Vitro Bioactivity of $\mathrm{SiO}(2)-\mathrm{CaO}-\mathrm{P}(2) \mathrm{O}(5)-\mathrm{MgO}$ Sol-Gel Glasses. J. Biomed. Mater. Res. 1999, 47, 170-175. [CrossRef]

13. Chen, W.-C.; Kung, J.-C.; Chen, C.-H.; Hsiao, Y.-C.; Shih, C.-J.; Chien, C.-S. Effects of Bioactive Glass with and without Mesoporous Structures on Desensitization in Dentinal Tubule Occlusion. Appl. Surf. Sci. 2013, 283, 833-842. [CrossRef]

14. Soulié, J.; Hardy-Dessources, A.; Nedelec, J.-M.; Jallot, E. 3D Organized Macroporous Bioactive Glasses: A Study of Pore Size Effect on Physicochemical Reactivity by Micro-PIXE-RBS. J. Phys. Chem. C 2013, 117, 6702-6711. [CrossRef]

15. Kresge, C.T.; Leonowicz, M.E.; Roth, W.J.; Vartuli, J.C.; Beck, J.S. Ordered Mesoporous Molecular Sieves Synthesized by a Liquid-Crystal Template Mechanism. Nature 1992, 359, 710-712. [CrossRef]

16. Holland, B.T.; Blanford, C.F.; Do, T.; Stein, A. Synthesis of Highly Ordered, Three-Dimensional, Macroporous Structures of Amorphous or Crystalline Inorganic Oxides, Phosphates, and Hybrid Composites. Chem. Mater. 1999, 11, 795-805. [CrossRef]

17. Wang, X.; Liu, Q.; Chen, W.; Liu, L. FGF Adsorbed Mesoporous Bioactive Glass with Larger Pores in Enhancing Bone Tissue Engineering. J. Mater. Sci. Mater. Med. 2019, 30, 48. [CrossRef]

18. López-Noriega, A.; Arcos, D.; Izquierdo-Barba, I.; Sakamoto, Y.; Terasaki, O.; Vallet-Regí, M. Ordered Mesoporous Bioactive Glasses for Bone Tissue Regeneration. Chem. Mater. 2006, 18, 3137-3144. [CrossRef]

19. Wu, L.; Wei, Z.; He, S.; Bi, Y.; Cao, Y.; Wang, W. Mesoporous Bioactive Glass Scaffold Delivers Salvianolic Acid B to Promote Bone Regeneration in a Rat Cranial Defect Model. Curr. Drug Deliv. 2020, 17. [CrossRef]

20. Wang, X.; Cheng, F.; Liu, J.; Smått, J.-H.; Gepperth, D.; Lastusaari, M.; Xu, C.; Hupa, L. Biocomposites of Copper-Containing Mesoporous Bioactive Glass and Nanofibrillated Cellulose: Biocompatibility and Angiogenic Promotion in Chronic Wound Healing Application. Acta Biomater. 2016, 46, 286-298. [CrossRef]

21. Mocquot, C.; Colon, P.; Fernando, D.; Jackson, P.; Pradelle-Plasse, N.; Grosgogeat, B.; Attik, N. The Infuence of Experimental Bioactive Glasses on Pulp Cells Behavior in Vitro. Dent. Mater. 2020, 36, 1322-1331. [CrossRef] [PubMed]

22. Mao, C.; Chen, X.; Hu, Q.; Miao, G.; Lin, C. Acute Toxicity and in Vivo Biodistribution of Monodispersed Mesoporous Bioactive Glass Spheres in Intravenously Exposed Mice. Mater. Sci. Eng. C 2016, 58, 682-691. [CrossRef] [PubMed]

23. Anand, A.; Lalzawmliana, V.; Kumar, V.; Das, P.; Devi, K.B.; Maji, A.K.; Kundu, B.; Roy, M.; Nandi, S.K. Preparation and in Vivo Biocompatibility Studies of Different Mesoporous Bioactive Glasses. J. Mech. Behav. Biomed. Mater. 2019, 89, 89-98. [CrossRef] [PubMed]

24. Ghamor-Amegavi, E.P.; Yang, X.; Qiu, J.; Xie, L.; Pan, Z.; Wang, J.; Zhang, X.; Ke, X.; Zhao, T.; Zhang, L.; et al. Composition Control in Biphasic Silicate Microspheres on Stimulating New Bone Regeneration and Repair of Osteoporotic Femoral Bone Defect. J. Biomed. Mater. Res. 2020, 108, 377-390. [CrossRef] [PubMed]

25. Lalzawmliana, V.; Anand, A.; Kumar, V.; Das, P.; Devi, K.B.; Mukherjee, J.; Maji, A.K.; Kundu, B.; Roy, M.; Nandi, S.K. Potential of Growth Factor Incorporated Mesoporous Bioactive Glass for in Vivo Bone Regeneration. J. Mech. Behav. Biomed. Mater. 2019, 91, 182-192. [CrossRef]

26. Li, Y.; Bastakoti, B.P.; Yamauchi, Y. Smart Soft-Templating Synthesis of Hollow Mesoporous Bioactive Glass Spheres. Chem. Eur. J. 2015, 21, 8038-8042. [CrossRef]

27. Garg, S.; Thakur, S.; Gupta, A.; Kaur, G.; Pandey, O.P. Antibacterial and Anticancerous Drug Loading Kinetics for (10-x)CuOXZnO-20CaO-60SiO2-10P2O5 $(2 \leq \mathrm{x} \leq 8)$ Mesoporous Bioactive Glasses. J. Mater. Sci. Mater. Med. 2017, 28, 11. [CrossRef]

28. Jiang, S.; Zhang, Y.; Shu, Y.; Wu, Z.; Cao, W.; Huang, W. Amino-Functionalized Mesoporous Bioactive Glass for Drug Delivery. Biomed. Mater. 2017, 12, 025017. [CrossRef]

29. Shoaib, M.; Saeed, A.; Rahman, M.S.U.; Naseer, M.M. Mesoporous Nano-Bioglass Designed for the Release of Imatinib and in Vitro Inhibitory Effects on Cancer Cells. Mater. Sci. Eng. C 2017, 77, 725-730. [CrossRef]

30. Baino, F.; Fiume, E.; Miola, M.; Leone, F.; Onida, B.; Laviano, F.; Gerbaldo, R.; Verné, E. Fe-Doped Sol-Gel Glasses and GlassCeramics for Magnetic Hyperthermia. Materials 2018, 11, 173. [CrossRef]

31. Baino, F.; Potestio, I.; Vitale-Brovarone, C. Production and Physicochemical Characterization of Cu-Doped Silicate Bioceramic Scaffolds. Materials 2018, 11, 1524. [CrossRef] [PubMed]

32. Fernando, D.; Colon, P.; Cresswell, M.; Journet, C.; Pradelle-Plasse, N.; Jackson, P.; Grosgogeat, B.; Attik, N. The Influence of Precursor Addition Order on the Porosity of Sol-Gel Bioactive Glasses. Dent. Mater. 2018, 34, 1323-1330. [CrossRef] [PubMed] 
33. Kargozar, S.; Baino, F.; Hamzehlou, S.; Hill, R.G.; Mozafari, M. Bioactive Glasses Entering the Mainstream. Drug Discov. Today 2018, 23, 1700-1704. [CrossRef] [PubMed]

34. Nawaz, Q.; Rehman, M.A.U.; Burkovski, A.; Schmidt, J.; Beltrán, A.M.; Shahid, A.; Alber, N.K.; Peukert, W.; Boccaccini, A.R. Synthesis and Characterization of Manganese Containing Mesoporous Bioactive Glass Nanoparticles for Biomedical Applications. J. Mater. Sci. Mater. Med. 2018, 29, 64. [CrossRef]

35. Liu, X.; Chen, H.-H.; Lin, Y.-C.; Nabilla, S.C.; Liu, W.-C.; Wang, W.-C.; Shih, S.-J.; Li, Y.; Lin, C.-P.; Zhao, G.; et al. Composite Polyelectrolyte Multilayer and Mesoporous Bioactive Glass Nanoparticle Coating on 316L Stainless Steel for Controlled Antibiotic Release and Biocompatibility. J. Biomed. Nanotechnol. 2018, 14, 725-735. [CrossRef]

36. Mubina, M.S.K.; Shailajha, S.; Sankaranarayanan, R.; Saranya, L. In Vitro Bioactivity, Mechanical Behavior and Antibacterial Properties of Mesoporous SiO2-CaO-Na2O-P2O5 Nano Bioactive Glass Ceramics. J. Mech. Behav. Biomed. Mater. 2019, 100, 103379. [CrossRef]

37. Shadjou, N.; Hasanzadeh, M. Silica-Based Mesoporous Nanobiomaterials as Promoter of Bone Regeneration Process: Bone Regeneration Process Using Silica-Based Mesoporous Nanobiomaterials. J. Biomed. Mater. Res. 2015, 103, 3703-3716. [CrossRef]

38. Baino, F.; Fiorilli, S.; Vitale-Brovarone, C. Bioactive Glass-Based Materials with Hierarchical Porosity for Medical Applications: Review of Recent Advances. Acta Biomater. 2016, 42, 18-32. [CrossRef]

39. Galarraga-Vinueza, M.E.; Mesquita-Guimarães, J.; Magini, R.S.; Souza, J.C.M.; Fredel, M.C.; Boccaccini, A.R. Anti-Biofilm Properties of Bioactive Glasses Embedding Organic Active Compounds: Bioactive glasses embedding organic active compounds. J. Biomed. Mater. Res. 2017, 105, 672-679. [CrossRef]

40. Vichery, C.; Nedelec, J.-M. Bioactive Glass Nanoparticles: From Synthesis to Materials Design for Biomedical Applications. Materials 2016, 9, 288. [CrossRef]

41. Fiume, E.; Barberi, J.; Verné, E.; Baino, F. Bioactive Glasses: From Parent 45S5 Composition to Scaffold-Assisted Tissue-Healing Therapies. J. Funct. Biomater. 2018, 9, 24. [CrossRef] [PubMed]

42. Kargozar, S.; Montazerian, M.; Hamzehlou, S.; Kim, H.-W.; Baino, F. Mesoporous Bioactive Glasses: Promising Platforms for Antibacterial Strategies. Acta Biomater. 2018, 81, 1-19. [CrossRef] [PubMed]

43. Kaya, S.; Cresswell, M.; Boccaccini, A.R. Mesoporous Silica-Based Bioactive Glasses for Antibiotic-Free Antibacterial Applications. Mater. Sci. Eng. C 2018, 83, 99-107. [CrossRef]

44. Wu, J.; Yang, L.; Li, Y.; Guo, L. Research progress on mesoporous bioactive glass. Sheng Wu Yi Xue Gong Cheng Xue Za Zhi 2018, 4, 647-650. [CrossRef]

45. Lalzawmliana, V.; Anand, A.; Roy, M.; Kundu, B.; Nandi, S.K. Mesoporous Bioactive Glasses for Bone Healing and Biomolecules Delivery. Mater. Sci. Eng. C 2020, 106, 110180. [CrossRef]

46. Gisbert-Garzarán, M.; Manzano, M.; Vallet-Regí, M. Mesoporous Silica Nanoparticles for the Treatment of Complex Bone Diseases: Bone Cancer, Bone Infection and Osteoporosis. Pharmaceutics 2020, 12, 83. [CrossRef]

47. Sistanipour, E.; Meshkini, A.; Oveisi, H. Catechin-Conjugated Mesoporous Hydroxyapatite Nanoparticle: A Novel NanoAntioxidant with Enhanced Osteogenic Property. Colloids Surf. B Biointerf. 2018, 169, 329-339. [CrossRef]

48. Wu, Y.; Zhang, W.; Zhang, J.; Mao, Z.-X.; Ding, L.; Li, H.; Ma, R.; Tang, J.-H. Methionine Functionalized Biocompatible Block Copolymers for Targeted Plasmid DNA Delivery. J. Vis. Exp. 2019, 58527. [CrossRef]

49. Lin, D.; Yang, K.; Tang, W.; Liu, Y.; Yuan, Y.; Liu, C. A Poly(Glycerol Sebacate)-Coated Mesoporous Bioactive Glass Scaffold with Adjustable Mechanical Strength, Degradation Rate, Controlled-Release and Cell Behavior for Bone Tissue Engineering. Colloids Surf. B Biointerf. 2015, 131, 1-11. [CrossRef]

50. Min, Z.; Shichang, Z.; Chen, X.; Yufang, Z.; Changqing, Z. 3D-Printed Dimethyloxallyl Glycine Delivery Scaffolds to Improve Angiogenesis and Osteogenesis. Biomater. Sci. 2015, 3, 1236-1244. [CrossRef]

51. Gómez-Cerezo, N.; Sánchez-Salcedo, S.; Izquierdo-Barba, I.; Arcos, D.; Vallet-Regí, M. In Vitro Colonization of Stratified Bioactive Scaffolds by Pre-Osteoblast Cells. Acta Biomater. 2016, 44, 73-84. [CrossRef] [PubMed]

52. Han, X.; Lin, H.; Guo, G.; Qu, F.; Chen, X.; Li, X. One-Step Method for the Preparation of Poly(Methyl Methacrylate) Modified Titanium-Bioactive Glass Three-Dimensional Scaffolds for Bone Tissue Engineering. IET Nanobiotechnol. 2016, 10, 45-53. [CrossRef] [PubMed]

53. Hesaraki, S. Photocurable Bioactive Bone Cement Based on Hydroxyethyl Methacrylate-Poly(Acrylic/Maleic) Acid Resin and Mesoporous Sol Gel-Derived Bioactive Glass. Mater. Sci. Eng. C 2016, 63, 535-545. [CrossRef] [PubMed]

54. Kim, T.-H.; Singh, R.K.; Kang, M.S.; Kim, J.-H.; Kim, H.-W. Inhibition of Osteoclastogenesis through SiRNA Delivery with Tunable Mesoporous Bioactive Nanocarriers. Acta Biomater. 2016, 29, 352-364. [CrossRef] [PubMed]

55. Pourshahrestani, S.; Zeimaran, E.; Adib Kadri, N.; Gargiulo, N.; Samuel, S.; Naveen, S.V.; Kamarul, T.; Towler, M.R. GalliumContaining Mesoporous Bioactive Glass with Potent Hemostatic Activity and Antibacterial Efficacy. J. Mater. Chem. B 2016, 4, 71-86. [CrossRef]

56. Singh, R.K.; Patel, K.D.; Mahapatra, C.; Kang, M.S.; Kim, H.-W. C-Dot Generated Bioactive Organosilica Nanospheres in Theranostics: Multicolor Luminescent and Photothermal Properties Combined with Drug Delivery Capacity. ACS Appl. Mater. Interfaces 2016, 8, 24433-24444. [CrossRef] [PubMed]

57. Tang, W.; Lin, D.; Yu, Y.; Niu, H.; Guo, H.; Yuan, Y.; Liu, C. Bioinspired Trimodal Macro/Micro/Nano-Porous Scaffolds Loading RhBMP-2 for Complete Regeneration of Critical Size Bone Defect. Acta Biomater. 2016, 32, 309-323. [CrossRef] 
58. Vishnu Priya, M.; Sivshanmugam, A.; Boccaccini, A.R.; Goudouri, O.M.; Sun, W.; Hwang, N.; Deepthi, S.; Nair, S.V.; Jayakumar, R. Injectable Osteogenic and Angiogenic Nanocomposite Hydrogels for Irregular Bone Defects. Biomed. Mater. 2016, $11,035017$. [CrossRef]

59. Wu, T.; Cheng, N.; Xu, C.; Sun, W.; Yu, C.; Shi, B. The Effect of Mesoporous Bioglass on Osteogenesis and Adipogenesis of Osteoporotic BMSCs. J. Biomed. Mater. Res. A 2016, 104, 3004-3014. [CrossRef]

60. Zhang, X.; Zeng, D.; Li, N.; Jiang, X.; Liu, C.; Li, Y. Large-Pore Mesoporous Ca-Si-Based Bioceramics with High in Vitro Bioactivity and Protein Adsorption Capability for Bone Tissue Regeneration. J. Mater. Chem. B 2016, 4, 3916-3924. [CrossRef]

61. Zhang, X.; Zeng, D.; Li, N.; Wen, J.; Jiang, X.; Liu, C.; Li, Y. Functionalized Mesoporous Bioactive Glass Scaffolds for Enhanced Bone Tissue Regeneration. Sci. Rep. 2016, 6, 19361. [CrossRef] [PubMed]

62. Ge, F.; Yu, M.; Yu, C.; Lin, J.; Weng, W.; Cheng, K.; Wang, H. Improved RhBMP-2 Function on MBG Incorporated TiO2 Nanorod Films. Colloids Surf. B Biointerfaces 2017, 150, 153-158. [CrossRef] [PubMed]

63. Kaur, G.; Sriranganathan, N.; Waldrop, S.G.; Sharma, P.; Chudasama, B.N. Effect of Copper on the Up-Regulation/down-Regulation of Genes, Cytotoxicity and Ion Dissolution for Mesoporous Bioactive Glasses. Biomed. Mater. 2017, 12, 045020. [CrossRef] [PubMed]

64. Li, X.; Zhao, L.; Liang, Q.; Ye, J.; Komatsu, N.; Zhang, Q.; Gao, W.; Xu, M.; Chen, X. Cationic Polyarginine Conjugated Mesoporous Bioactive Glass Nanoparticles with Polyglycerol Coating for Efficient DNA Delivery. J. Biomed. Nanotechnol. 2017, 13, 280-289. [CrossRef] [PubMed]

65. Luo, H.; Li, W.; Ao, H.; Li, G.; Tu, J.; Xiong, G.; Zhu, Y.; Wan, Y. Preparation, Structural Characterization, and in Vitro Cell Studies of Three-Dimensional SiO2-CaO Binary Glass Scaffolds Built Ofultra-Small Nanofibers. Mater. Sci. Eng. C 2017, 76, 94-101. [CrossRef] [PubMed]

66. Luo, H.; Zhang, Y.; Li, G.; Tu, J.; Yang, Z.; Xiong, G.; Wang, Z.; Huang, Y.; Wan, Y. Sacrificial Template Method for the Synthesis of Three-Dimensional Nanofibrous 58S Bioglass Scaffold and Its in Vitro Bioactivity and Cell Responses. J. Biomater. Appl. 2017, 32, 265-275. [CrossRef] [PubMed]

67. Pourshahrestani, S.; Zeimaran, E.; Kadri, N.A.; Gargiulo, N.; Jindal, H.M.; Naveen, S.V.; Sekaran, S.D.; Kamarul, T.; Towler, M.R. Potency and Cytotoxicity of a Novel Gallium-Containing Mesoporous Bioactive Glass/Chitosan Composite Scaffold as Hemostatic Agents. ACS Appl. Mater. Interfaces 2017, 9, 31381-31392. [CrossRef]

68. Qi, X.; Pei, P.; Zhu, M.; Du, X.; Xin, C.; Zhao, S.; Li, X.; Zhu, Y. Three Dimensional Printing of Calcium Sulfate and Mesoporous Bioactive Glass Scaffolds for Improving Bone Regeneration in Vitro and in Vivo. Sci. Rep. 2017, 7, 42556. [CrossRef]

69. Sánchez-Salcedo, S.; García, A.; Vallet-Regí, M. Prevention of Bacterial Adhesion to Zwitterionic Biocompatible Mesoporous Glasses. Acta Biomater. 2017, 57, 472-486. [CrossRef]

70. Schumacher, M.; Reither, L.; Thomas, J.; Kampschulte, M.; Gbureck, U.; Lode, A.; Gelinsky, M. Calcium Phosphate Bone Cement/Mesoporous Bioactive Glass Composites for Controlled Growth Factor Delivery. Biomater. Sci. 2017, 5, 578-588. [CrossRef]

71. Shoaib, M.; Saeed, A.; Akhtar, J.; Rahman, M.S.U.; Ullah, A.; Jurkschat, K.; Naseer, M.M. Potassium-Doped Mesoporous Bioactive Glass: Synthesis, Characterization and Evaluation of Biomedical Properties. Mater. Sci. Eng. C 2017, 75, 836-844. [CrossRef] [PubMed]

72. Wang, X.; Chen, W.; Liu, Q.; Gao, K.; Wang, G.; Gao, L.; Liu, L. Function and Mechanism of Mesoporous Bioactive Glass Adsorbed Epidermal Growth Factor for Accelerating Bone Tissue Regeneration. Biomed. Mater. 2017, 12, 025020. [CrossRef] [PubMed]

73. Xin, T.; Gu, Y.; Cheng, R.; Tang, J.; Sun, Z.; Cui, W.; Chen, L. Inorganic Strengthened Hydrogel Membrane as Regenerative Periosteum. ACS Appl. Mater. Interfaces 2017, 9, 41168-41180. [CrossRef] [PubMed]

74. Xue, Y.; Guo, Y.; Yu, M.; Wang, M.; Ma, P.X.; Lei, B. Monodispersed Bioactive Glass Nanoclusters with Ultralarge Pores and Intrinsic Exceptionally High MiRNA Loading for Efficiently Enhancing Bone Regeneration. Adv. Healthc. Mater. 2017, 6, 1700630. [CrossRef] [PubMed]

75. Yu, M.; Xue, Y.; Ma, P.X.; Mao, C.; Lei, B. Intrinsic Ultrahigh Drug/MiRNA Loading Capacity of Biodegradable Bioactive Glass Nanoparticles toward Highly Efficient Pharmaceutical Delivery. ACS Appl. Mater. Interfaces 2017, 9, 8460-8470. [CrossRef]

76. Cai, L.; Lin, D.; Chai, Y.; Yuan, Y.; Liu, C. MBG Scaffolds Containing Chitosan Microspheres for Binary Delivery of IL-8 and BMP-2 for Bone Regeneration. J. Mater. Chem. B 2018, 6, 4453-4465. [CrossRef] [PubMed]

77. Covarrubias, C.; Cádiz, M.; Maureira, M.; Celhay, I.; Cuadra, F.; von Marttens, A. Bionanocomposite Scaffolds Based on ChitosanGelatin and Nanodimensional Bioactive Glass Particles: In Vitro Properties and in Vivo Bone Regeneration. J. Biomater. Appl. 2018, 32, 1155-1163. [CrossRef]

78. Fiorilli, S.; Molino, G.; Pontremoli, C.; Iviglia, G.; Torre, E.; Cassinelli, C.; Morra, M.; Vitale-Brovarone, C. The Incorporation of Strontium to Improve Bone-Regeneration Ability of Mesoporous Bioactive Glasses. Materials 2018, 11, 678. [CrossRef]

79. Gómez-Cerezo, N.; Casarrubios, L.; Morales, I.; Feito, M.J.; Vallet-Regí, M.; Arcos, D.; Portolés, M.T. Effects of a Mesoporous Bioactive Glass on Osteoblasts, Osteoclasts and Macrophages. J. Colloid Interface Sci. 2018, 528, 309-320. [CrossRef]

80. Hsu, F.-Y.; Hsu, H.-W.; Chang, Y.-H.; Yu, J.-L.; Rau, L.-R.; Tsai, S.-W. Macroporous Microbeads Containing Apatite-Modified Mesoporous Bioactive Glass Nanofibres for Bone Tissue Engineering Applications. Mater. Sci. Eng. C 2018, 89, 346-354. [CrossRef]

81. Jia, X.; Miron, R.J.; Yin, C.; Xu, H.; Luo, T.; Wang, J.; Jia, R.; Wu, M.; Zhang, Y.; Li, Y. HnRNPL Inhibits the Osteogenic Differentiation of PDLCs Stimulated by $\mathrm{SrCl}_{2}$ through Repressing Setd2. J. Cell. Mol. Med. 2019, 23, 2667-2677. [CrossRef] [PubMed]

82. Kumar, A.; Aditya, A.; Murugavel, S. Effect of Surfactant Concentration on Textural Characteristics and Biomineralization Behavior of Mesoporous Bioactive Glasses. Mater. Sci. Eng. C 2019, 96, 20-29. [CrossRef] [PubMed]

83. Mandakhbayar, N.; El-Fiqi, A.; Lee, J.-H.; Kim, H.-W. Evaluation of Strontium-Doped Nanobioactive Glass Cement for DentinPulp Complex Regeneration Therapy. ACS Biomater. Sci. Eng. 2019, 5, 6117-6126. [CrossRef] 
84. Pourshahrestani, S.; Kadri, N.A.; Zeimaran, E.; Gargiulo, N.; Samuel, S.; Naveen, S.V.; Hasikin, K.; Kamarul, T.; Towler, M.R. Comparative Efficacy of Hemorrhage Control of a Novel Mesoporous Bioactive Glass versus Two Commercial Hemostats. Biomed. Mater. 2018, 13, 025020. [CrossRef] [PubMed]

85. Qi, X.; Wang, H.; Zhang, Y.; Pang, L.; Xiao, W.; Jia, W.; Zhao, S.; Wang, D.; Huang, W.; Wang, Q. Mesoporous Bioactive Glass-Coated 3D Printed Borosilicate Bioactive Glass Scaffolds for Improving Repair of Bone Defects. Int. J. Biol. Sci. 2018, 14, 471-484. [CrossRef]

86. Shoaib, M.; Ur Rahman, M.S.; Saeed, A.; Naseer, M.M. Mesoporous Bioactive Glass-Polyurethane Nanocomposites as Reservoirs for Sustained Drug Delivery. Colloids Surf. B Biointerfaces 2018, 172, 806-811. [CrossRef] [PubMed]

87. Zeng, D.; Zhang, X.; Wang, X.; Huang, Q.; Wen, J.; Miao, X.; Peng, L.; Li, Y.; Jiang, X. The Osteoimmunomodulatory Properties of MBG Scaffold Coated with Amino Functional Groups. Artif. Cells Nanomed. Biotechnol. 2018, 46, 1425-1435. [CrossRef]

88. Du, X.; Wei, D.; Huang, L.; Zhu, M.; Zhang, Y.; Zhu, Y. 3D Printing of Mesoporous Bioactive Glass/Silk Fibroin Composite Scaffolds for Bone Tissue Engineering. Mater. Sci. Eng. C 2019, 103, 109731. [CrossRef]

89. Fu, S.; Du, X.; Zhu, M.; Tian, Z.; Wei, D.; Zhu, Y. 3D Printing of Layered Mesoporous Bioactive Glass/Sodium Alginate-Sodium Alginate Scaffolds with Controllable Dual-Drug Release Behaviors. Biomed. Mater. 2019, 14, 065011. [CrossRef]

90. Gómez-Cerezo, N.; Casarrubios, L.; Saiz-Pardo, M.; Ortega, L.; de Pablo, D.; Díaz-Güemes, I.; Fernández-Tomé, B.; Enciso, S.; Sánchez-Margallo, F.M.; Portolés, M.T.; et al. Mesoporous Bioactive Glass/ $\epsilon$-Polycaprolactone Scaffolds Promote Bone Regeneration in Osteoporotic Sheep. Acta Biomater. 2019, 90, 393-402. [CrossRef]

91. Li, S.; Song, C.; Yang, S.; Yu, W.; Zhang, W.; Zhang, G.; Xi, Z.; Lu, E. Supercritical CO2 Foamed Composite Scaffolds Incorporating Bioactive Lipids Promote Vascularized Bone Regeneration via Hif- $1 \alpha$ Upregulation and Enhanced Type H Vessel Formation. Acta Biomater. 2019, 94, 253-267. [CrossRef] [PubMed]

92. Liu, T.; Chen, Y.; Lai, D.; Zhang, L.; Pan, X.; Chen, J.; Weng, H. Biomimetic Fabrication of New Bioceramics-Introduced Fibrous Scaffolds: From Physicochemical Characteristics to in Vitro Biological Properties. Mater. Sci. Eng. C 2019, 94, 547-557. [CrossRef] [PubMed]

93. Montalbano, G.; Borciani, G.; Pontremoli, C.; Ciapetti, G.; Mattioli-Belmonte, M.; Fiorilli, S.; Vitale-Brovarone, C. Development and Biocompatibility of Collagen-Based Composites Enriched with Nanoparticles of Strontium Containing Mesoporous Glass. Materials 2019, 12, 3719. [CrossRef] [PubMed]

94. Pourshahrestani, S.; Zeimaran, E.; Kadri, N.A.; Gargiulo, N.; Jindal, H.M.; Hasikin, K.; Naveen, S.V.; Sekaran, S.D.; Kamarul, T. Elastomeric Biocomposite of Silver-Containing Mesoporous Bioactive Glass and Poly(1,8-Octanediol Citrate): Physiochemistry and in Vitro Antibacterial Capacity in Tissue Engineering Applications. Mater. Sci. Eng. C 2019, 98, 1022-1033. [CrossRef]

95. Terzopoulou, Z.; Baciu, D.; Gounari, E.; Steriotis, T.; Charalambopoulou, G.; Tzetzis, D.; Bikiaris, D. Composite Membranes of Poly( $\varepsilon$-Caprolactone) with Bisphosphonate-Loaded Bioactive Glasses for Potential Bone Tissue Engineering Applications. Molecules 2019, 24, 3067. [CrossRef]

96. Varini, E.; Sánchez-Salcedo, S.; Malavasi, G.; Lusvardi, G.; Vallet-Regí, M.; Salinas, A.J. Cerium (III) and (IV) Containing Mesoporous Glasses/Alginate Beads for Bone Regeneration: Bioactivity, Biocompatibility and Reactive Oxygen Species Activity. Mater. Sci. Eng. C 2019, 105, 109971. [CrossRef]

97. Wang, W.; Liu, Y.; Yang, C.; Qi, X.; Li, S.; Liu, C.; Li, X. Mesoporous Bioactive Glass Combined with Graphene Oxide Scaffolds for Bone Repair. Int. J. Biol. Sci. 2019, 15, 2156-2169. [CrossRef]

98. Wu, J.; Miao, G.; Zheng, Z.; Li, Z.; Ren, W.; Wu, C.; Li, Y.; Huang, Z.; Yang, L.; Guo, L. 3D Printing Mesoporous Bioactive Glass/Sodium Alginate/Gelatin Sustained Release Scaffolds for Bone Repair. J. Biomater. Appl. 2019, 33, 755-765. [CrossRef]

99. Zhang, C.; Yuan, Y.; Fang, L.; Xuan, Y. Promotion of Osteogenesis by Bioactive Glass-Ceramic Coating: Possible Involvement of the Hedgehog Signaling Pathway. J. Orthop. Sci. 2019, 24, 731-736. [CrossRef]

100. Zheng, K.; Kang, J.; Rutkowski, B.; Gawęda, M.; Zhang, J.; Wang, Y.; Founier, N.; Sitarz, M.; Taccardi, N.; Boccaccini, A.R. Toward Highly Dispersed Mesoporous Bioactive Glass Nanoparticles With High Cu Concentration Using Cu/Ascorbic Acid Complex as Precursor. Front. Chem. 2019, 7, 497. [CrossRef]

101. Berkmann, J.C.; Herrera Martin, A.X.; Pontremoli, C.; Zheng, K.; Bucher, C.H.; Ellinghaus, A.; Boccaccini, A.R.; Fiorilli, S.; Vitale Brovarone, C.; Duda, G.N.; et al. In Vivo Validation of Spray-Dried Mesoporous Bioactive Glass Microspheres Acting as Prolonged Local Release Systems for BMP-2 to Support Bone Regeneration. Pharmaceutics 2020, 12, 823. [CrossRef] [PubMed]

102. Chitra, S.; Bargavi, P.; Balakumar, S. Effect of Microwave and Probe Sonication Processes on Sol-Gel-derived Bioactive Glass and Its Structural and Biocompatible Investigations. J. Biomed. Mater. Res. 2020, 108, 143-155. [CrossRef] [PubMed]

103. Montalbano, G.; Borciani, G.; Cerqueni, G.; Licini, C.; Banche-Niclot, F.; Janner, D.; Sola, S.; Fiorilli, S.; Mattioli-Belmonte, M.; Ciapetti, G.; et al. Collagen Hybrid Formulations for the 3D Printing of Nanostructured Bone Scaffolds: An Optimized Genipin-Crosslinking Strategy. Nanomaterials 2020, 10, 1681. [CrossRef] [PubMed]

104. Montes-Casado, M.; Sanvicente, A.; Casarrubios, L.; Feito, M.J.; Rojo, J.M.; Vallet-Regí, M.; Arcos, D.; Portolés, P.; Portolés, M.T. An Immunological Approach to the Biocompatibility of Mesoporous SiO2-CaO Nanospheres. Int. J. Mol. Sci. 2020, 21, 8291. [CrossRef]

105. Pontremoli, C.; Izquierdo-Barba, I.; Montalbano, G.; Vallet-Regí, M.; Vitale-Brovarone, C.; Fiorilli, S. Strontium-Releasing Mesoporous Bioactive Glasses with Anti-Adhesive Zwitterionic Surface as Advanced Biomaterials for Bone Tissue Regeneration. J. Colloid Interface Sci. 2020, 563, 92-103. [CrossRef]

106. Wang, X.; Chen, W.; Liu, Q.; Liu, L. Genistein Adsorbed Mesoporous Bioactive Glass with Enhanced Osteogenesis Properties. Biotechnol. Lett. 2020, 42, 321-328. [CrossRef] 
107. Zhou, J.; Xiong, Z.; Liu, M.; Yang, L.; Yao, S.; Chen, K.; Yu, K.; Qu, Y.; Sun, T.; Guo, X. Creation of Bony Microenvironment with Extracellular Matrix Doped-Bioactive Ceramics to Enhance Osteoblast Behavior and Delivery of Aspartic Acid-Modified BMP-2 Peptides. Int. J. Nanomed. 2020, 15, 8465-8478. [CrossRef]

108. Zhou, L.; Fan, L.; Zhang, F.-M.; Jiang, Y.; Cai, M.; Dai, C.; Luo, Y.-A.; Tu, L.-J.; Zhou, Z.-N.; Li, X.-J.; et al. Hybrid Gelatin/Oxidized Chondroitin Sulfate Hydrogels Incorporating Bioactive Glass Nanoparticles with Enhanced Mechanical Properties, Mineralization, and Osteogenic Differentiation. Bioact. Mater. 2021, 6, 890-904. [CrossRef]

109. Zemke, F.; Schölch, V.; Bekheet, M.F.; Schmidt, F. Surfactant-Assisted Sol-Gel Synthesis of Mesoporous Bioactive Glass Microspheres. Nanomater. Energy 2019, 8, 126-134. [CrossRef]

110. Poliakoff, M. Green Chemistry: Science and Politics of Change. Science 2002, 297, 807-810. [CrossRef]

111. Dang, T.H.; Bui, T.H.; Guseva, E.V.; Ta, A.T.; Nguyen, A.T.; Hoang, T.T.H.; Bui, X.V. Characterization of Bioactive Glass Synthesized by Sol-Gel Process in Hot Water. Crystals 2020, 10, 529. [CrossRef]

112. Arcos, D.; López-Noriega, A.; Ruiz-Hernández, E.; Terasaki, O.; Vallet-Regí, M. Ordered Mesoporous Microspheres for Bone Grafting and Drug Delivery. Chem. Mater. 2009, 21, 1000-1009. [CrossRef]

113. Wu, C.; Chang, J. Mesoporous Bioactive Glasses: Structure Characteristics, Drug/Growth Factor Delivery and Bone Regeneration Application. Interface Focus 2012, 2, 292-306. [CrossRef] [PubMed]

114. Fernando, D.; Attik, N.; Pradelle-Plasse, N.; Jackson, P.; Grosgogeat, B.; Colon, P. Bioactive Glass for Dentin Remineralization: A Systematic Review. Mater. Sci. Eng. C 2017, 76, 1369-1377. [CrossRef] [PubMed]

115. Deshmukh, K.; Kovář́k, T.; Křenek, T.; Docheva, D.; Stich, T.; Pola, J. Recent Advances and Future Perspectives of Sol-Gel Derived Porous Bioactive Glasses: A Review. RSC Adv. 2020, 10, 33782-33835. [CrossRef]

116. Jung, J.-H.; Park, S.-B.; Yoo, K.-H.; Yoon, S.-Y.; Bae, M.-K.; Lee, D.J.; Ko, C.-C.; Kwon, Y.H.; Kim, Y.-I. Effect of Different Sizes of Bioactive Glass-Coated Mesoporous Silica Nanoparticles on Dentinal Tubule Occlusion and Mineralization. Clin. Oral Invest. 2019, 23, 2129-2141. [CrossRef] [PubMed]

117. Han, P.; Wu, C.; Chang, J.; Xiao, Y. The Cementogenic Differentiation of Periodontal Ligament Cells via the Activation of Wnt/ $\beta$-Catenin Signalling Pathway by Li+ Ions Released from Bioactive Scaffolds. Biomaterials 2012, 33, 6370-6379. [CrossRef]

118. Zhou, Y.; Han, S.; Xiao, L.; Han, P.; Wang, S.; He, J.; Chang, J.; Wu, C.; Xiao, Y. Accelerated Host Angiogenesis and Immune Responses by Ion Release from Mesoporous Bioactive Glass. J. Mater. Chem. B 2018, 6, 3274-3284. [CrossRef]

119. Kermani, F.; Mollazadeh Beidokhti, S.; Baino, F.; Gholamzadeh-Virany, Z.; Mozafari, M.; Kargozar, S. Strontium- and Cobalt-Doped Multicomponent Mesoporous Bioactive Glasses (MBGs) for Potential Use in Bone Tissue Engineering Applications. Materials 2020, 13, 1348. [CrossRef]

120. Miyoshi, H.; Adachi, T.; Ju, J.; Lee, S.M.; Cho, D.J.; Ko, J.S.; Uchida, G.; Yamagata, Y. Characteristics of Motility-Based Filtering of Adherent Cells on Microgrooved Surfaces. Biomaterials 2012, 33, 395-401. [CrossRef]

121. Cobb, L. Cell Proliferation Assays and Cell Viability Assays. Mater. Methods 2020. [CrossRef]

122. Pintor, A.V.B.; Queiroz, L.D.; Barcelos, R.; Primo, L.S.G.; Maia, L.C.; Alves, G.G. MTT versus Other Cell Viability Assays to Evaluate the Biocompatibility of Root Canal Filling Materials: A Systematic Review. Int. Endod. J. 2020, 53, 1348-1373. [CrossRef] [PubMed]

123. ISO 10993. Biological Evaluation of Dental Devices; International Organization for Standardization: Geneva, Switzerland, 2018.

124. Treccani, L.; Yvonne Klein, T.; Meder, F.; Pardun, K.; Rezwan, K. Functionalized Ceramics for Biomedical, Biotechnological and Environmental Applications. Acta Biomater. 2013, 9, 7115-7150. [CrossRef] [PubMed]

125. Kaur, G.; Pickrell, G.; Sriranganathan, N.; Kumar, V.; Homa, D. Review and the State of the Art: Sol-Gel and Melt Quenched Bioactive Glasses for Tissue Engineering: Review and State of the Art Of Bioactive Glasses. J. Biomed. Mater. Res. 2016, 104, 1248-1275. [CrossRef]

126. Baino, F.; Fiume, E. 3D Printing of Hierarchical Scaffolds Based on Mesoporous Bioactive Glasses (MBGs)—Fundamentals and Applications. Materials 2020, 13, 1688. [CrossRef]

127. Gentleman, E.; Fredholm, Y.C.; Jell, G.; Lotfibakhshaiesh, N.; O'Donnell, M.D.; Hill, R.G.; Stevens, M.M. The Effects of StrontiumSubstituted Bioactive Glasses on Osteoblasts and Osteoclasts in Vitro. Biomaterials 2010, 31, 3949-3956. [CrossRef]

128. Abbasi, Z.; Bahrololoom, M.; Shariat, M.; Bagheri, R. Bioactive Glasses in Dentistry: A Review. J. Dent. Biomater. 2015,2 , 1-9.

129. Saffarpour, M.; Mohammadi, M.; Tahriri, M.; Zakerzadeh, A. Efficacy of Modified Bioactive Glass for Dentin Remineralization and Obstruction of Dentinal Tubules. J. Dent. (Tehran) 2017, 14, 212-222.

130. Chitra, S.; Bargavi, P.; Balasubramaniam, M.; Chandran, R.R.; Balakumar, S. Impact of Copper on In-Vitro Biomineralization, Drug Release Efficacy and Antimicrobial Properties of Bioactive Glasses. Mater. Sci. Eng. C 2020, 109, 110598. [CrossRef]

131. Wu, C.; Xia, L.; Han, P.; Mao, L.; Wang, J.; Zhai, D.; Fang, B.; Chang, J.; Xiao, Y. Europium-Containing Mesoporous Bioactive Glass Scaffolds for Stimulating in Vitro and in Vivo Osteogenesis. ACS Appl. Mater. Interfaces 2016, 8, 11342-11354. [CrossRef]

132. Izquierdo-Barba, I.; Vallet-Regí, M. Mesoporous Bioactive Glasses: Relevance of Their Porous Structure Compared to That of Classical Bioglasses. Biomed. Glasses 2015, 1. [CrossRef]

133. Baino, F.; Fiorilli, S.; Vitale-Brovarone, C. Composite Biomaterials Based on Sol-Gel Mesoporous Silicate Glasses: A Review. Bioengineering 2017, 4, 15. [CrossRef] [PubMed]

134. Anselme, K.; Davidson, P.; Popa, A.M.; Giazzon, M.; Liley, M.; Ploux, L. The Interaction of Cells and Bacteria with Surfaces Structured at the Nanometre Scale. Acta Biomater. 2010, 6, 3824-3846. [CrossRef] [PubMed]

135. Alamoush, R.A.; Kushnerev, E.; Yates, J.M.; Satterthwaite, J.D.; Silikas, N. Response of Two Gingival Cell Lines to CAD/CAM Composite Blocks. Dent. Mater. 2020, 36, 1214-1225. [CrossRef] [PubMed] 
136. Johnson, H.J.; Northup, S.J.; Seagraves, P.A.; Garvin, P.J.; Wallin, R.F. Biocompatibility Test Procedures for Materials Evaluationin Vitro. I. Comparative Test System Sensitivity. J. Biomed. Mater. Res. 1983, 17, 571-586. [CrossRef]

137. Wilkesmann, S.; Fellenberg, J.; Nawaz, Q.; Reible, B.; Moghaddam, A.; Boccaccini, A.R.; Westhauser, F. Primary Osteoblasts, Osteoblast Precursor Cells or Osteoblast-like Cell Lines: Which Human Cell Types Are (Most) Suitable for Characterizing 45S5-bioactive Glass? J. Biomed. Mater. Res. 2020, 108, 663-674. [CrossRef]

138. Bragdon, B.; Burns, R.; Baker, A.H.; Belkina, A.C.; Morgan, E.F.; Denis, G.V.; Gerstenfeld, L.C.; Schlezinger, J.J. Intrinsic Sex-Linked Variations in Osteogenic and Adipogenic Differentiation Potential of Bone Marrow Multipotent Stromal Cells: Age- and Sex-Linked Variation in MSC Differentiation. J. Cell. Physiol. 2015, 230, 296-307. [CrossRef]

139. Widholz, B.; Tsitlakidis, S.; Reible, B.; Moghaddam, A.; Westhauser, F. Pooling of Patient-Derived Mesenchymal Stromal Cells Reduces Inter-Individual Confounder-Associated Variation without Negative Impact on Cell Viability, Proliferation and Osteogenic Differentiation. Cells 2019, 8, 633. [CrossRef]

140. Adan, A.; Kiraz, Y.; Baran, Y. Cell Proliferation and Cytotoxicity Assays. Curr. Pharmaceut. Biotechnol. 2016, 17, 1213-1221. [CrossRef]

141. Bopp, S.K.; Lettieri, T. Comparison of Four Different Colorimetric and Fluorometric Cytotoxicity Assays in a Zebrafish Liver Cell Line. BMC Pharmacol 2008, 8, 8. [CrossRef]

142. Cobb, L. Cell Based Assays: The Cell Cycle, Cell Proliferation and Cell Death. Mater. Methods 2013, 3. [CrossRef]

143. Gong, W.; Huang, Z.; Dong, Y.; Gan, Y.; Li, S.; Gao, X.; Chen, X. Ionic Extraction of a Novel Nano-Sized Bioactive Glass Enhances Differentiation and Mineralization of Human Dental Pulp Cells. J. Endod. 2014, 40, 83-88. [CrossRef] [PubMed]

144. Johnson, H.J.; Northup, S.J.; Seagraves, P.A.; Atallah, M.; Garvin, P.J.; Lin, L.; Darby, T.D. Biocompatibility Test Procedures for Materials Evaluationin Vitro. II. Objective Methods of Toxicity Assessment. J. Biomed. Mater. Res. 1985, 19, 489-508. [CrossRef] [PubMed]

145. Keong, L.C.; Halim, A.S. In Vitro Models in Biocompatibility Assessment for Biomedical-Grade Chitosan Derivatives in Wound Management. Int. J. Mol. Sci. 2009, 10, 1300-1313. [CrossRef]

146. ISO 7405. Evaluation of Biocompatibility of Medical Devices Used in Dentistry n.d. 2018. Available online: https://www.iso.org/ standard/71503.html (accessed on 12 February 2020). 